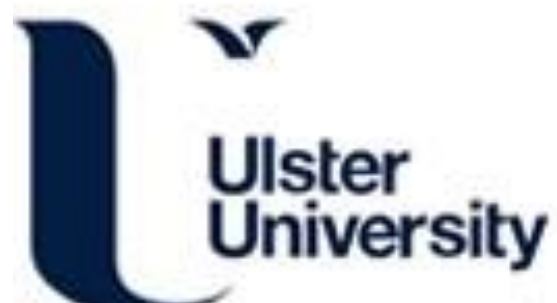

\section{Options for Small and Medium Scale Power Generation from Biomass}

Mcllveen-Wright, D., Williams, BC., \& McMullan, JT. (1999). Options for Small and Medium Scale Power Generation from Biomass. Developments in Chemical Engineering \& Mineral Processing, 7(1-2), 85-114. https://doi.org/10.1002/apj.5500070109

Link to publication record in Ulster University Research Portal

\section{Published in:}

Developments in Chemical Engineering \& Mineral Processing

Publication Status:

Published (in print/issue): 01/09/1999

DOI:

10.1002/apj.5500070109

\section{Document Version}

Publisher's PDF, also known as Version of record

\section{General rights}

Copyright for the publications made accessible via Ulster University's Research Portal is retained by the author(s) and / or other copyright owners and it is a condition of accessing these publications that users recognise and abide by the legal requirements associated with these rights.

\section{Take down policy}

The Research Portal is Ulster University's institutional repository that provides access to Ulster's research outputs. Every effort has been made to ensure that content in the Research Portal does not infringe any person's rights, or applicable UK laws. If you discover content in the Research Portal that you believe breaches copyright or violates any law, please contact pure-support@ulster.ac.uk. 


\title{
Options for Small and Medium Scale Power Generation from Biomass
}

\author{
D. McIlveen-Wright" ${ }^{*}$ B. C. Williams and J. T. McMullan \\ Northern Ireland Centre for Energy Research and Technology, \\ University of Ulster, Coleraine BT52 1SA, N. Ireland
}

\begin{abstract}
The technical and economic performance of a variety of options for producing electric power from woody biomass are assessed using the ECLIPSE suite of computer programs. The studies have included both fixed and fluidised bed combustion and gasification of the biomass with power generation from a range of small and medium scale steam turbines, gas engines, fuel cells or gas turbines in conventional, STIGand ISTIG modes.

For the small-scale systems, gasification integrated with a gas engine was found to be the most appropriate of the current technologies, and gasification integrated with Molten Carbonate Fuel Cells the most promising technology for future development. For medium-scale systems, the IGCC systems were found to be the most efficient, but the less efficient combustion systems were competitive on cost. STIG and ISTIGsystems offer promise for the future.
\end{abstract}

\section{Introduction}

Wood offers advantages over fossil fuels with regards to emissions. The sulphur content of wood is minimal, so $\mathrm{SO}_{\mathrm{x}}$ emissions are negligible. Similarly, there is little nitrogen in wood, so if combustion temperatures are controlled to avoid oxidation of nitrogen from the air, $\mathrm{NO}_{\mathrm{x}}$ emissions will also be low. Wood can also be grown sustainably, whereby the wood taken from a plantation and used in a combustion plant can be replaced over a short timescale. This implies that an equivalent amount of $\mathrm{CO}_{2}$ to that produced in combustion will be taken up during the growth of the replacement wood, and that wood can be considered neutral with regard to $\mathrm{CO}_{2}$ emissions (Hall et al., 1993). In fact, if wood-fired plants replace fossil fuel plants, a reduction in emissions may be considered

\footnotetext{
*Author to whom correspondence should be addressed (telephone: 01265 324400; fax:
} 


\section{324900;Email:dr.mcilveen-wright@ulst.ac.uk)}

to occur, as well as a saving in the non-renewable fossil fuel resource. growing biomass planted to replace that used in the combustion plant. The use of sustainably-grown wood for power generation has undoubted benefits in terms of reduced emissions, security of fuel supply, alternative land use and long-term employment.

A range of technologies are currently available, or are being developed, which may be suitable for generating electricity using wood as the fuel. In this work some of the main technologies are assessed for their technical and economic performance at different plant sizes using a computer simulation package. The technologies reviewed here are : (a) combustion with or without wood drying; (b) gasification of the wood followed by power generation using a gas turbine only (Simple Cycle Gas Turbine or SGT); 8 Integrated Gasification Combined Cycle or IGCC; (d) Steam Injection Gas Turbine or STIG; (e) Intercooled Steam Injection Gas Turbine or ISTIG; (f) wood gasification followed by a spark ignition gas engine; (g) wood gasification integrated with Molten Carbonate or Phosphoric Acid fuelcells (MCFC orPAFC).

\section{Computer Simulations}

The ECLIPSE process simulator (Williams et al., 1996), which has been successfully employed to model a range of power generation systems (McMullan et al., 1995), was used for these assessments. ECLIPSE is a process simulation package for the PC. It was designed to perform technical and economic evaluations of chemical and related processes, and so is very suitable for examining power plant. ECLIPSE is made up of a set of programs which are used to provide a step-by-step procedure for evaluating all the necessary parts of the technical and economic analysis of a process. The simulation of a process can be separated into seven steps or stages; four are for the technical evaluation and the remaining three for the economic evaluation.

These stages are as follows:

Stage 1 - Preparation of the process flow diagram.

Stage 2 - Addition of technical data to that process. 
Stage 3 - Calculation of the mass and energy balance.

Stage 4 - Calculation of the utilities usages.

Stage 5 - Estimation of the process and utilities capital costs.

Stage 6 - Calculation of the operating costs.

Stage 7 - Performance of the process economic evaluation.

In every case an individual mass and energy balance was optimised for the system chosen. The utilities (electricity, cooling water, etc) required by parts of the plant (e.g. fans, condenser) are then calculated by the following program module, or they can be inputted for non-standard components. Utilities data for some of the biomass-specific machinery (conveyor, chipper,etc) were acquired (Bridgwater et al., 1991) and entered to complete the technical assessment.

Several elements in the simulations cannot be precisely determined, for various reasons, and certain values are assumed in all cases. For example, the wood feedstock is taken to be willow from a short rotation forestry plantation with a moisture content of $100 \%$ (on a dry basis), the annual plantation yield as 10 dry tonnes/ ha, discounted cash flow rate (DCF) as $7.5 \%$ and contingency as $10 \%$. For all systems it is further assumed that the wood is harvested from a local coppiced plantation, is then chipped and transported to the power plant where it is stored in piles in the open, in sufficient quantities for 5 - 14 days' throughput. Next, the chips are taken from storage, screened (with magnetic separation, size separation and reduction stages) and transferred to buffer storage, ready for use in the combustor or gasifier. Wood feedstock costs are assumed to be made up of ,19.80/ dry tonne for harvesting and chipping plus , 0.31 / dry tonne/ km for transportation (Dawson, 1992).

In the economic analysis capital costs are study estimates with an accuracy of " 30\%. Capital costs are difficult to determine for any novel technology, and it is especially difficult to estimate how much they will change after the technology has undergone intensive development and large scale production. The best available capital cost estimates have been used ((Bridgwater et al., 1991), (Solantausta et al., 1995).

Certain parameters have been chosen to use in the comparison of the various technologies. For the technical features of the systems the efficiency (Lower Heating Value) for electricity 
generation is used. Break-even Electricity Selling Price (BESP), total capital cost and Specific Investment (SI, which is the Capital cost per installed kilowatt of electricity output) are takenas the economic parameters. Although sustainably grown wood is assumed to be used as the fuel, $\mathrm{CO}_{2}$ is emitted and the amount of $\mathrm{CO}_{2}$ emissions is used as a monitor of the environmental impact of the system.

A more complete description of all the analyses presented here, except for the fuel cell systems, is given elsewhere (McIlveen-Wright et al., 1997). An analysis of the fuel cell systems (McIlveen-Wright D.R., 1996), the wood combustion systems (McIlveen-Wright D. et al., December 1995) and a comparison of the wood combustion with IGCC systems (McIlveenWright D. et al., July 1995) have also been reported.

\section{Combustion}

A range of plant sizes were examined, using from 10 to 2,000 dry ash-free (daf) tonnes of wood per day. A simulation was made with and without a drying stage for each plant size. Where a drying stage is used, low pressure steam heats the air used in a rotary dryer where the wood moisture content is reduced to $15 \%$ (dry basis). Approximately $15 \%$ excess air, preheated by the exhaust gases, is used in the combustor to ensure complete combustion of the wood. Steam conditions appropriate for each plant size were chosen i.e. 23 bar at 350EC for the 10 daf tonnes/ day size, 60 bar at 480EC for the 100 daf tonnes/ day plants, 80 bar at $520 \mathrm{EC}$ for the 500, 1,000 and 2,000 daf tonnes/ day plants.

The most important results for the wet and dried wood combustion systems are summarised in Tables 1 and 2, and the break-even electricity selling price (BESP) for these plants is shown against plant size (as measured by plant wood-handling capacity) in Figure 1.

The ADried Wood@ Combustion systems are generally a little more efficient than the plants using AWet Wood@ (see Tables 1 and 2), but they also cost more to build and produce electricity a little more expensively. The electrical efficiency of combustion systems is low, so a lot of heat goes to waste. When this waste heat is used to dry the fuelwood prior to entering the combustion area, this wood can be combusted more efficiently in the furnace, since less energy is needed to drive off moisture before it can be burned. 
Table 1. Dried Wood Combustion (10 - 2,000 daf Tonnes/day)

\begin{tabular}{||c|r|r|r|r|r||}
\hline Fuel Flow (daf Tonnes/day) & 10 & 100 & 500 & 1,000 & 2,000 \\
\hline Nominal Power Output (MWe) & 0.33 & 4.81 & 26.5 & 53.3 & 107 \\
\hline Overall Efficiency (LHV)(\%) & 16.6 & 23.9 & 26.4 & 26.5 & 26.6 \\
\hline $\mathrm{CO}_{2}$ Emissions (g/kWh) & 2,320 & 1,590 & 1,440 & 1,440 & 1,430 \\
\hline Capital Cost in, Million & 2.6 & 10.2 & 36 & 56 & 101 \\
\hline Specific Investment (,/kWe) & 7,900 & 2,100 & 1,400 & 1,000 & 950 \\
\hline BESP (p/kWh) & $\mathbf{2 1 . 5}$ & $\mathbf{6 . 8}$ & $\mathbf{4 . 9}$ & $\mathbf{4 . 5}$ & $\mathbf{4 . 4}$ \\
\hline Wood Price (,/daf tonne) & 20.0 & 20.5 & 21.5 & 25.1 & 27.3 \\
\hline
\end{tabular}


$\mathrm{BESP}=$ Break-even Electricity Selling Price for 7.5\% DCF and stated fuel price.

Table 2.AAsReceived@orAWet@Wood Combustion (10-2,000daf Tonnes/day)

\begin{tabular}{||l|r|r|r|r|r||}
\hline Fuel Flow (daf Tonnes/day) & 10 & 100 & 500 & 1,000 & 2,000 \\
\hline Nominal Power Output (MWe) & 0.35 & 4.7 & 25.5 & 51.2 & 103 \\
\hline Overall Efficiency (LHV)(\%) & 17.5 & 23.1 & 25.4 & 25.4 & 25.5 \\
\hline $\mathrm{CO}_{2}$ Emissions (g/kWh) & 2,190 & 1,650 & 1,500 & 1,500 & 1,490 \\
\hline Capital Cost in, Million & 2.3 & 8.6 & 29 & 45 & 81 \\
\hline
\end{tabular}

\section{EFFICIENCY v. PLANT SIZE}

Wet and Dried Wood Combustion

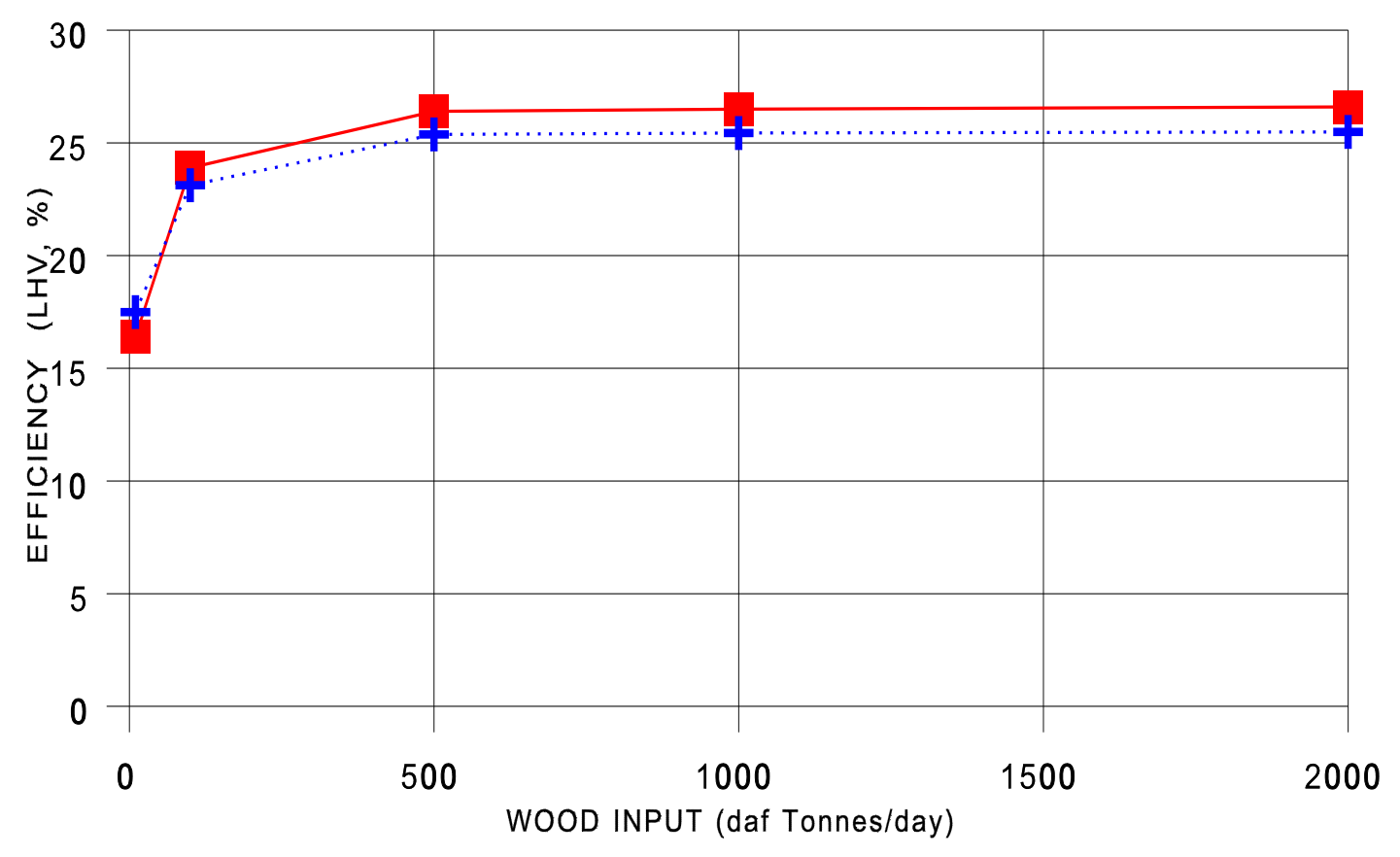

- DRIED WOOD $\quad \cdots+\cdots$ WET WOOD

\begin{tabular}{||l|l|l|l|l|r||}
\hline Specific Investment $(, / \mathrm{kWe})$ & 6,700 & 1,900 & 1,100 & 900 & 800 \\
\hline
\end{tabular}




\begin{tabular}{||l|r|r|r|r|r||}
\hline BESP $(\mathrm{p} / \mathrm{kWh})^{* *}$ & $\mathbf{1 8 . 3}$ & $\mathbf{6 . 2}$ & $\mathbf{4 . 5}$ & $\mathbf{4 . 2}$ & $\mathbf{4 . 1}$ \\
\hline Wood Price (,/daf tonne) & 20.0 & 20.5 & 21.5 & 25.1 & 27.3 \\
\hline
\end{tabular}

** $\quad$ BESP $=$ Break-even Electricity Selling Price for 7.5\% DCF and stated fuel price.

The smaller plants, using less than 500 daf tonnes/day, are very inefficient and expensive and therefore are not suitable for power generation by direct combustion. These sizes of plants are more suitable for application to combined heat and power situations.

\section{Summary of Discussion on Wood Combustion}

! Net electrical efficiency, $\eta$, was found to be principally determined by the steam

BESP V. WOOD INPUT WET AND DRIED WOOD COMBUSTION, DCF at $7.5 \%$

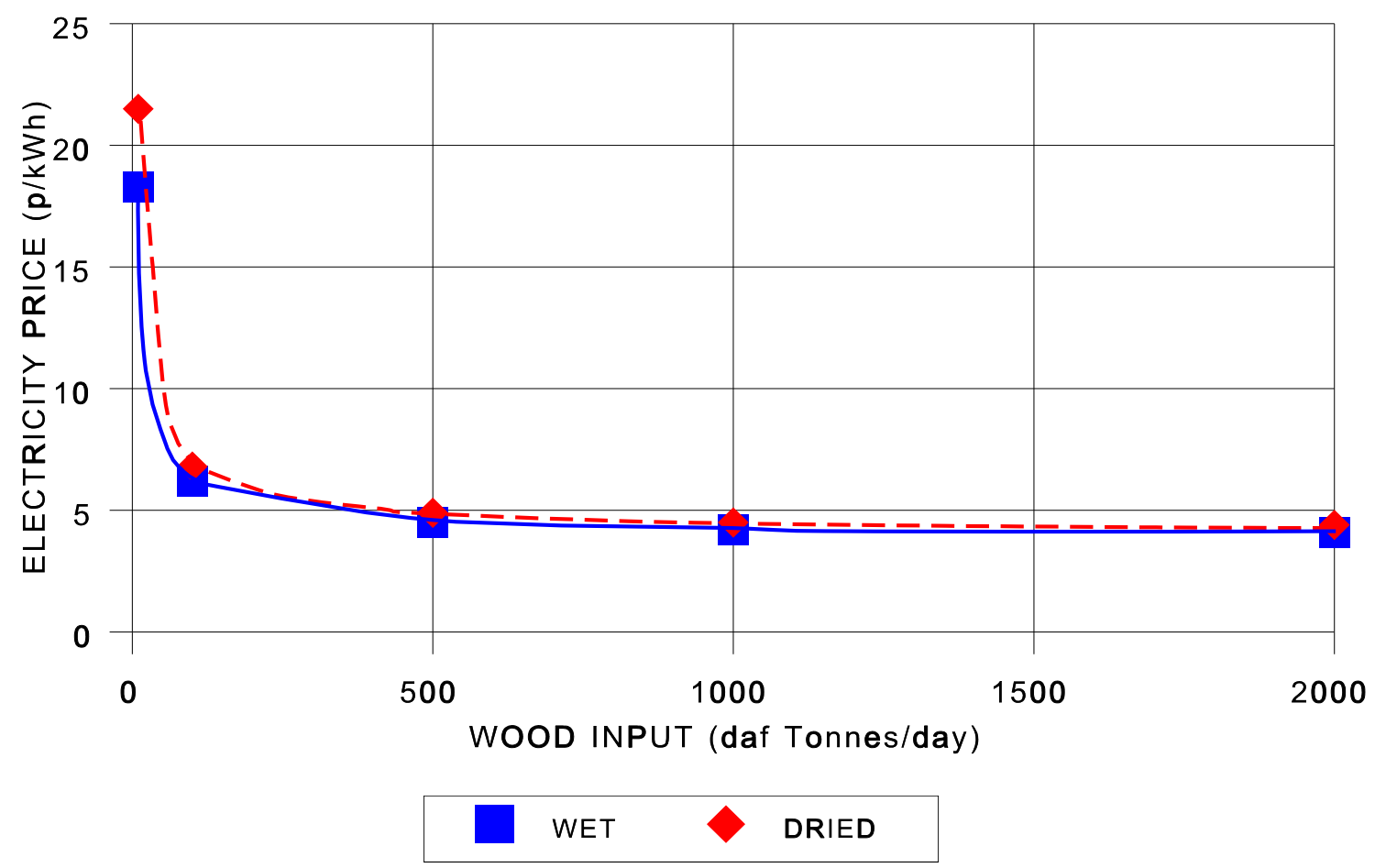

conditions and not by the base load linked to plant size. However, larger plants tend to 
have steam conditions more favourable for high efficiencies. A drying stage generally improves $\eta$.

! For small plants, plentiful wood supplies are available and transportation costs are low, but low $\eta$ and high capital costs make them uncompetitive.

! Medium- to large-sized combustion plants, using from 500 to 2,000 dry tonnes/ day, (25-110 MWe) probably offer the optimum scale for this technology.

! For small systems the effect on BESP of the efficiency gains in using a drying stage is outweighed by the increase in capital costs. For larger systems there is no significant difference in BESP between systems with or without a drying stage.

\section{IGCC Systems}

In this paper wood-fed power plants using fluidised-bed gasifiers are investigated in three different IGCC configurations; pressurised gasifier with filter gas-cleaning (PGF system), pressurised gasifier with scrubber gas-cleaning (PGS system) and atmospheric pressure gasifier with scrubber gas-cleaning (AGS system). In these systems the wood feedstock undergoes thermochemical conversion to a low calorific value producer gas in a fluidised bed gasifier. This gas is cleaned of particulates before entering the gas turbine. If the gasifier operates at atmospheric pressure, the gas must be compressed afterwards to match the air pressure in the combustor. Within the gas turbine the gas is mixed with compressed air, combusted and the products of combustion are exhausted through the expander stages. The expander drives the internal air compressor (and the gas compression stage, where present) and also generates electricity. The exhaust gases are then used in the boiler and economiser stages of the steam cycle and finally preheat the air in the wood drying stage. Power is also obtained from the steam turbines in the steam cycle.

Data, such as gas turbine inlet and exhaust temperatures and compression ratio, from gas turbines for a range of power outputs have been used to produce a set of IGCC power plant simulations. First of all, data for the chosen gas turbine were used in a simulation of the standalone gas turbine with natural gas as the fuel. The data, i.e. gas turbine inlet and exhaust temperature, compression ratio, mass and air flow, were taken from manufacturers' 
specifications or from the Gas Turbine World Yearbook 92/93. The bleed pressure and flow rate of the turbine blade cooling air (used to cool the nozzle guide vane and the high pressure turbine blades), as well as the turbine polytropic efficiency were taken as parameters in orderto match the stated turbine inlet and exhaust temperatures and to achieve a power output within $5 \%$ of the nominal output. Once this has been done, the process is repeated with "wood" gas as the fuel. On this occasion, of the given data only the gas turbine inlet temperature (or for the aircraft engine, the gas turbine inlet temperature which gives the stated power turbine inlet temperature) is maintained by varying the gas flow, i.e. the mass flow of the "wood gas" in the gas turbine was adjusted to obtain the gas turbine inlet temperature (TIT) previously used when the turbine was fired with natural gas. (Since the calorific value of the wood gas is about 5 $\mathrm{MJ} / \mathrm{m}^{3}$, compared with $48 \mathrm{MJ} / \mathrm{m}^{3}$ for natural gas, much more wood gas is necessary to achieve the same temperature. This, of course, has consequences for the size of the gas turbine combustor and for the expander stage of the turbine. They may need to be redesigned to take into account the larger flow of wood gas/air mixture now being handled. (These modifications may mean that the gas turbines, particularly the industrial gas turbines, used for "wood" gas will vary considerably from the versions using natural gas. Costs would have to be incurred for these modifications. However, if the larger flow of exhaust gases leaves the combustor at the same TIT as in the case for natural gas, this would mean a greater electrical output for the turbines using "wood" gas.) The gas turbine exit temperature was allowed to "float" i.e. no effort was made to try to maintain it at the same levelas for natural gas. However, the quantity of air used in the turbine is much greater than that of the gas, so the total flow is not greatly increased.) The amount of wood feedstock was scaled to produce the required wood gas mass flow, which determines the gasifier size. The operating pressure of the gasifier is chosen to be in excess of the pressure in the combustion stage of the gas turbine to reflect the pressure loss in the combustor. Gas turbine models were chosen which would require wood feedstock inputs covering the range considered as most appropriate i.e. from around 200 to 2,000 daf Tonnes/day.

Four different gas turbine models were chosen to produce a range of sizes of IGCC power stations. Each was simulated for the three named IGCC configurations. 
The two larger gas turbine models, which were used in these simulations, are standard industrial gas turbines. These are characterised by low pressure ratios, long working life times and moderate efficiencies. The two smaller gas turbines are based on aircraft engines. These have high pressure ratios, higher efficiencies and shorter lifetimes (when used in aircraft). The lifetimes of the aero-engines, when used in industrial applications, is expected to be greater, since a) they will be used in continuous operation and not in stop-go or changing part load operation, b) gas is kinder to the gas turbine than aviation fuel, c) stronger, heavier bearings and fittings can be used since weight is less important in industrial applications.

\section{IGCC - PGS Systems}

The results for the wood gasification integrated combined cycle systems, featuring pressurised gasifiers and wet scrubbers for cold gas cleaning (PGS configuration), are summarised in the following table and figures.

The two smallest systems investigated are based on aeroderivative gas turbines and the other two use industrial gas turbines. The efficiency of the systems depend largely on the compression ratio of the gas turbine, which determines to a great extent the Turbine Inlet Temperature.

Table 4. IGCC Systems - PGS Configuration

\begin{tabular}{|l|r|r|r|r||}
\hline \hline Fuel Flow (daf Tonnes/day) & 380 & 920 & 1,130 & 2,370 \\
\hline Nominal Power Output (MWe) & 30.2 & 72.6 & 83.0 & 183 \\
\hline Overall Efficiency (LHV)(\%) & 39.7 & 39.1 & 36.5 & 38.4 \\
\hline CO $_{2}$ Emissions (g/kWh) & 960 & 970 & 1,050 & 990 \\
\hline Capital Cost in, Million & 68 & 128 & 148 & 245 \\
\hline
\end{tabular}




\begin{tabular}{|c|c|c|c|c|}
\hline Specific Investment $(, / \mathrm{kWe})$ & 2,250 & 1,770 & 1,780 & 1,340 \\
\hline $\mathrm{BESP}(\mathrm{p} / \mathrm{kWh})^{* *}$ & 6.5 & 5.5 & 5.7 & 4.7 \\
\hline Wood Price (,/daf tonne) & 21.25 & 24.87 & 25.42 & 27.93 \\
\hline
\end{tabular}

** $\quad$ BESP $=$ Break-even Electricity Selling Price for 7.5\% DCF and stated fuel price.

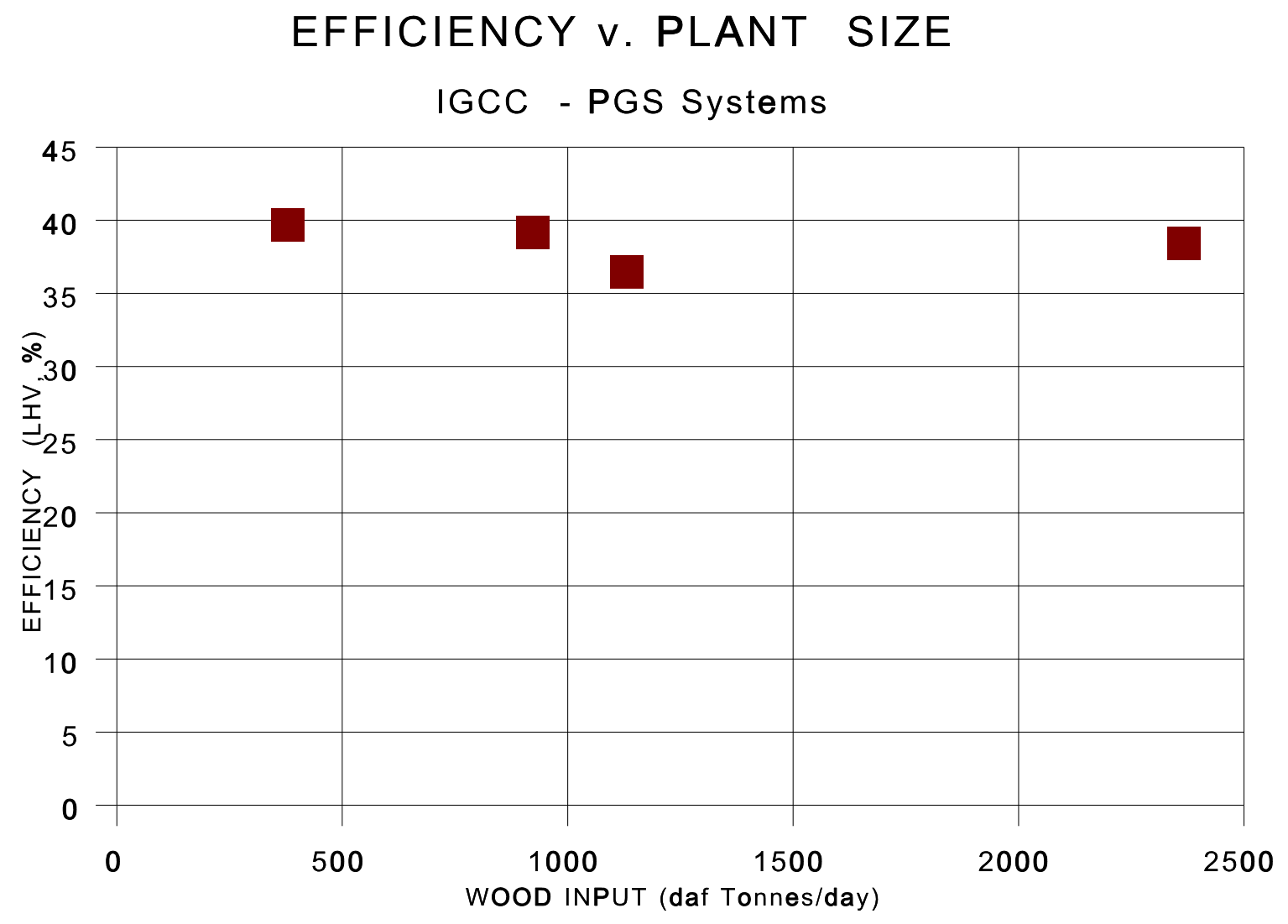




\section{BESP v. WOOD INPUT}

IGCC - PGS Systems

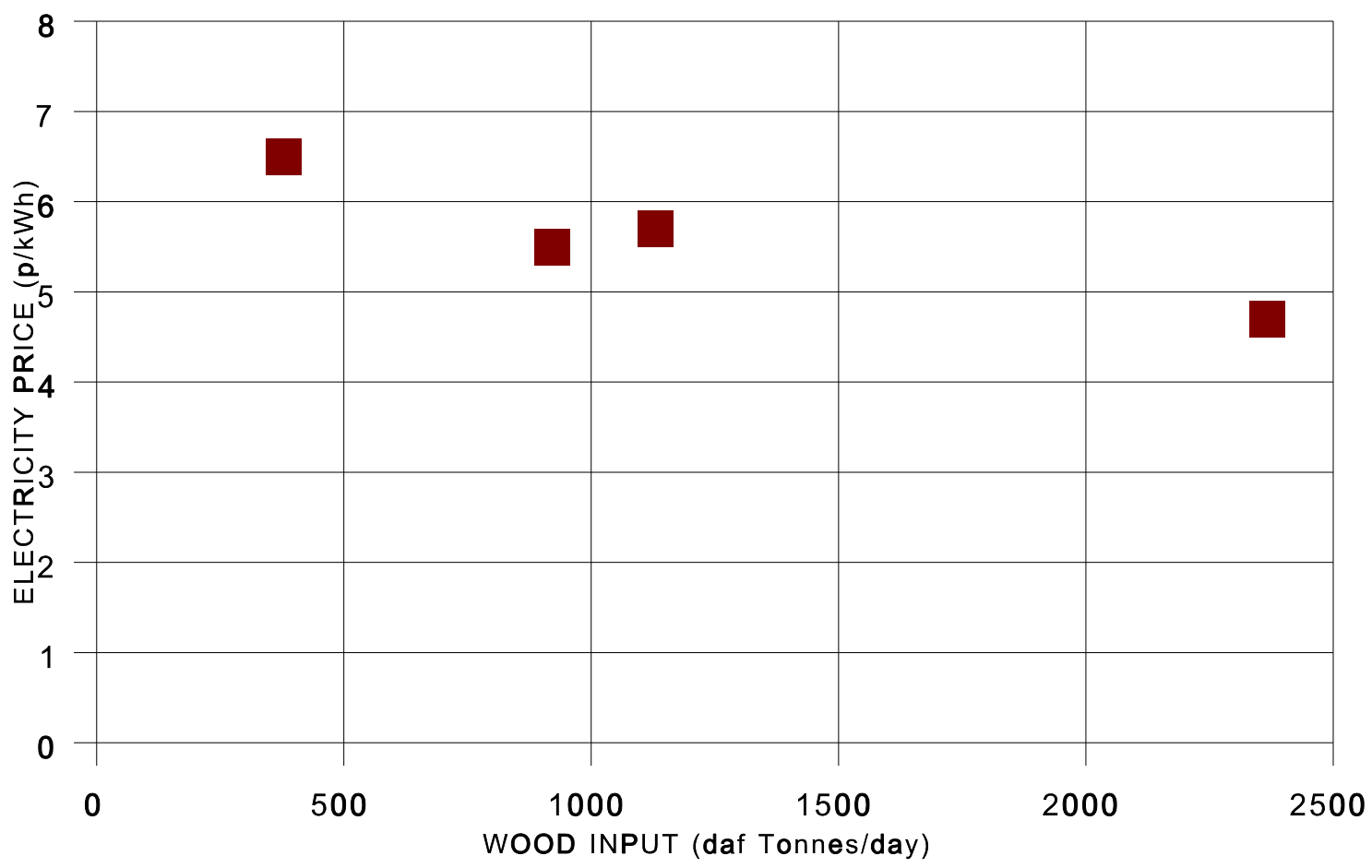

For BESP the value falls as the system size increases for the aeroderivative based systems and initially for the industrial gas turbine based systems.

\section{IGCC - PGF Systems}

The results for the wood gasification integrated combined cycle systems, featuring pressurised gasifiers and ceramic filters for hot gas cleaning (PGF configuration), are summarised in the following table and figures.

The variation in efficiency and BESP with system size is similar to that for the IGCC - PGS systems described above. Efficiencies, however, tend to be higher for the systems using the PGF configuration. 
Table 5. IGCC Systems - PGF Configuration

\begin{tabular}{|c|c|c|c|c|}
\hline Fuel Flow (daf Tonnes/day) & 300 & 735 & 915 & 1,920 \\
\hline Nominal Power Output (MWe) & 24.7 & 59.7 & 74.2 & 157.3 \\
\hline Overall Efficiency $(\mathrm{LHV})(\%)$ & 41.1 & 40.5 & 40.4 & 40.8 \\
\hline $\mathrm{CO}_{2}$ Emissions ( $\left.\mathrm{g} / \mathrm{kWh}\right)$ & 930 & 940 & 950 & 940 \\
\hline Capital Cost in, Million & 59 & 111 & 127 & 209 \\
\hline Specific Investment $(, / \mathrm{kWe})$ & 2,390 & 1,860 & 1,710 & 1,330 \\
\hline $\operatorname{BESP}(\mathrm{p} / \mathrm{kWh})^{* *}$ & 6.8 & 5.7 & 5.4 & 4.6 \\
\hline Wood Price (,/daf tonne) & 21.09 & 24.32 & 24.85 & 27.12 \\
\hline
\end{tabular}

** $\quad$ BESP $=$ Break-even Electricity Selling Price for 7.5\% DCF and stated fuel price. 


\section{IGCC - AGS Systems}

\section{EFFICIENCY v. PLANT SIZE \\ IGCC - PGF Systems}

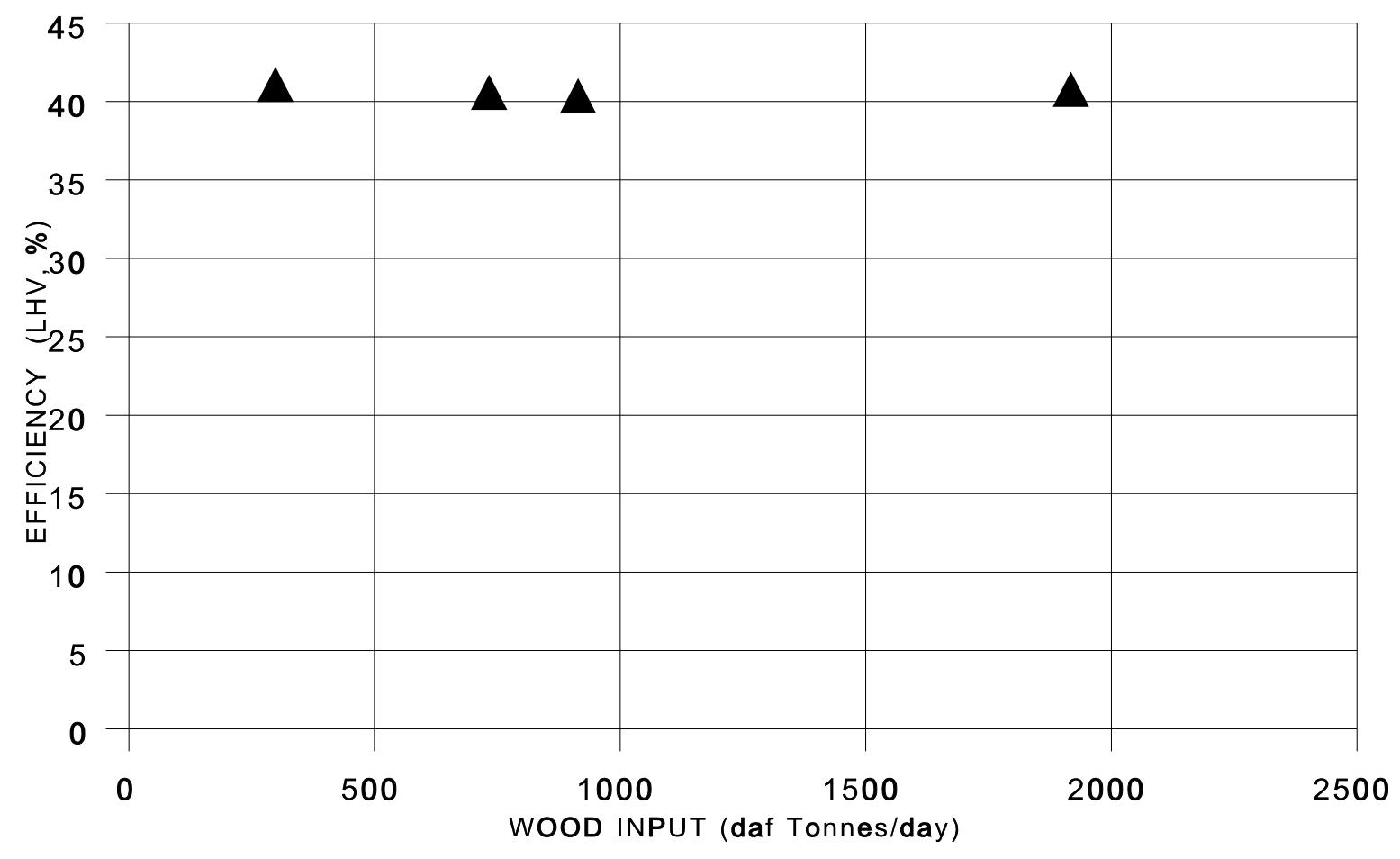




\section{BESP v. WOOD INPUT}

IGCC - PGF Systems

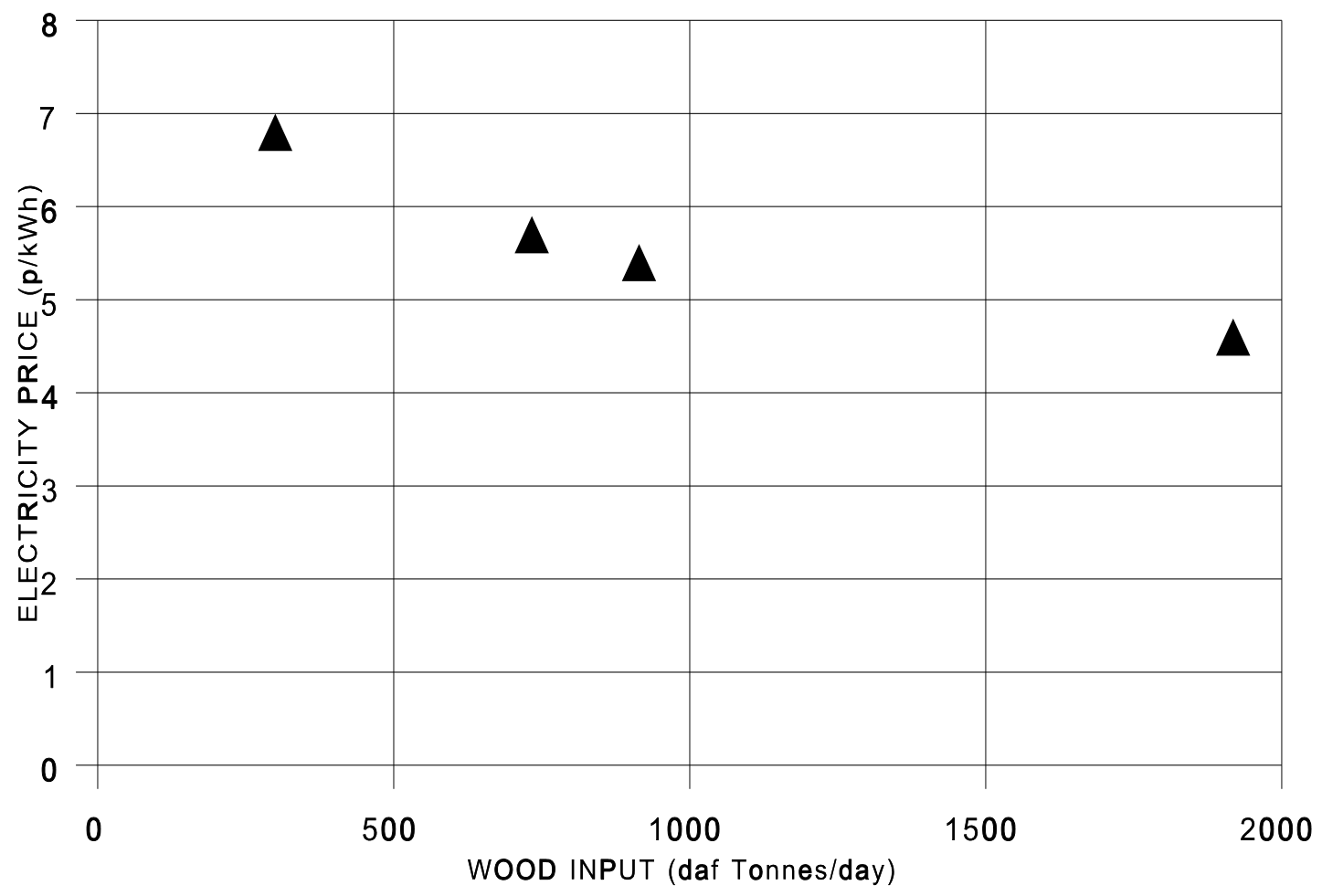

The results for the wood gasification integrated combined cycle systems, featuring atmospheric pressurise gasifiers and wet scrubbers for cold gas cleaning (AGS configuration), are summarised in the following table and figures.

Once again the variation in efficiency and BESP with system size is similar to that for the IGCC - PGS systems described earlier. Efficiencies, however, tend to be lower for the systems using the AGS configuration. 
Table 6. IGCC Systems - AGS Configuration

\begin{tabular}{||l|r|r|r|r||}
\hline \hline Fuel Flow (daf Tonnes/day) & 295 & 715 & 920 & 1,925 \\
\hline Nominal Power Output (MWe) & 20.5 & 48.3 & 58.0 & 124.9 \\
\hline Overall Efficiency (LHV)(\%) & 34.6 & 33.7 & 31.3 & 32.3 \\
\hline $\mathrm{CO}_{2}$ Emissions (g/kWh) & 1,100 & 1,130 & 1,220 & 1,180 \\
\hline Capital Cost in, Million & 51.4 & 93.8 & 109.2 & 187.8 \\
\hline Specific Investment (,/kWe) & 2,510 & 1,940 & 1,880 & 1,500 \\
\hline BESP (p/kWh) & $\mathbf{7 . 2}$ & $\mathbf{6 . 1}$ & $\mathbf{6 . 1}$ & $\mathbf{5 . 3}$ \\
\hline Wood Price (,/daf tonne) & 21.08 & 24.26 & 24.87 & 27.13 \\
\hline \hline
\end{tabular}

** $\quad$ BESP $=$ Break-even Electricity Selling Price for 7.5\% DCF and stated fuel price. 


\section{EFFICIENCY v. PLANT SIZE \\ IGCC - AGS Systems}

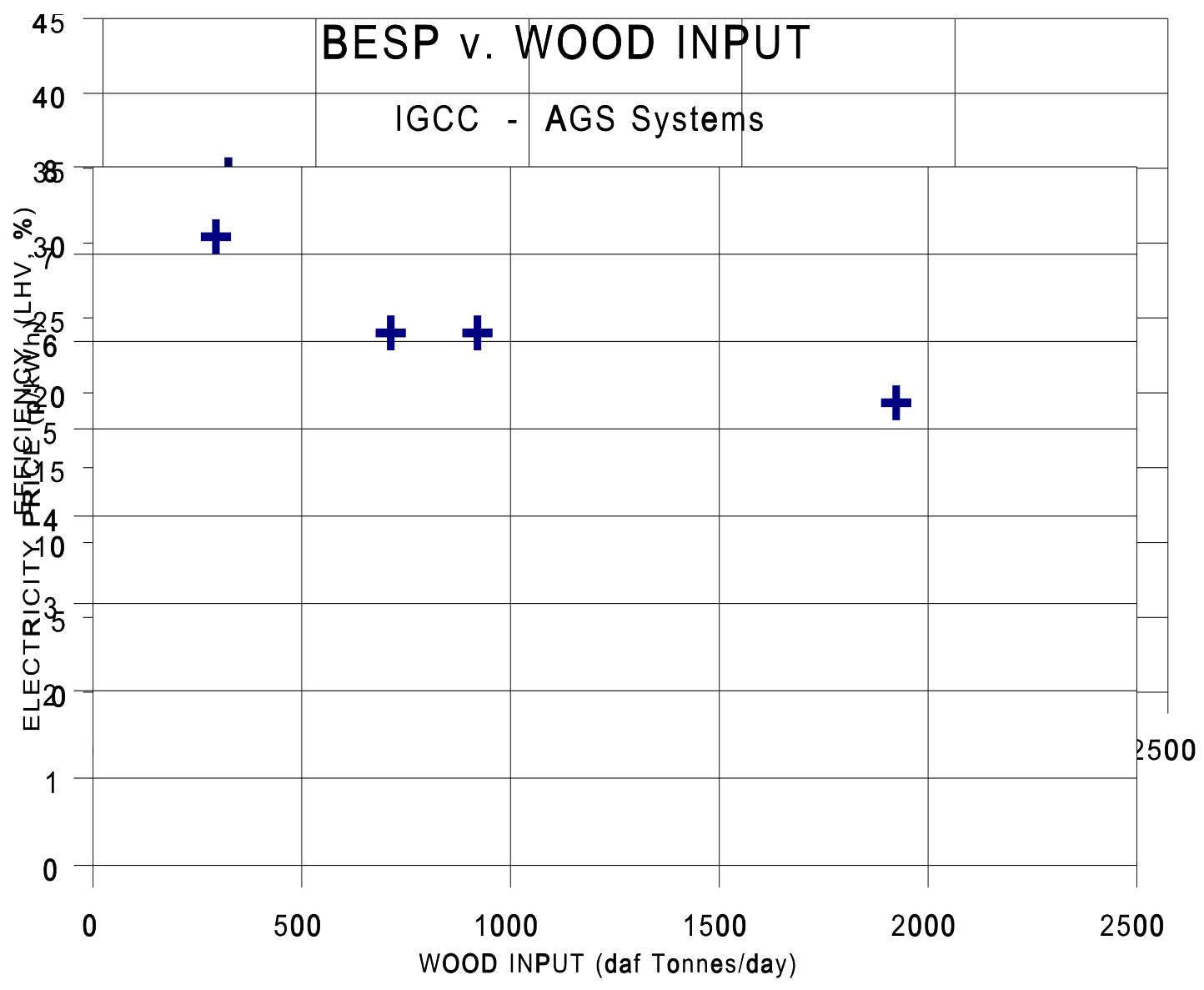

\section{Summary for IGCC Systems}

! Overall system efficiency was found to be improved by using hot gas clean-up (i.e. ceramic filter) and also by using a pressurised gasifier.

! Aero-derivative gas turbines are more efficient than industrial gas turbines; mainly due to their higher compression ratios. For the aero-derivatives, a higher Turbine Inlet Temperature (TIT) leads to higher $\eta$.

! Industrial gas turbines may need modifications to accommodate the low calorific value gas from wood i.e. larger combustor(s) and a larger expander. The costs of such 
modifications are difficult to assess, so the present economic analysis can only be considered as a guideline estimate. Aero-derivatives may need little or no modifications, since aircraft engines are designed to run under varying load, thrust and atmospheric conditions.

! Medium- to large-sized IGCC plants, using from 500 to 2,000 dry tonnes/ day (electrical output from around 50-160 MWe), probably offer the optimum scale forthis technology, but smaller IGCC plants based on other aero-derivative gas turbines, and on small gas turbines running in parallel, should be investigated.

\section{Gasification Integrated with Simple Cycle Gas Turbines (SGT)}

\section{Gas Turbines in the Standard Mode}

The results for wood gasification integrated with standard mode gas turbines in simple cycle systems, featuring atmospheric pressurise gasifiers and ceramic filters for hot gas cleaning, are summarised in the following table.

In these systems electrical efficiency rises and BESP falls as the plant size increases

Table 7. SGT Systems

\begin{tabular}{||l|r|r|r|r|r||}
\hline Fuel Flow (daf Tonnes/day) & 46 & 105 & 270 & 445 & 660 \\
\hline Gas Turbine Model & Hurricane & $\begin{array}{r}\text { Typhoon } \\
\text { (M) }\end{array}$ & LM1600 & LM2500 & LM5000 \\
\hline Nominal Power Output (MWe) & 1.3 & 3.4 & 12.4 & 18.9 & 29.0 \\
\hline Overall Efficiency (LHV)(\%) & 13.9 & 16.0 & 22.7 & 21.1 & 21.9 \\
\hline $\mathrm{CO}_{2}$ Emissions (g/kWh) & 2,750 & 2,390 & 1,680 & 1,810 & 1,740 \\
\hline
\end{tabular}




\begin{tabular}{||l|r|r|r|r|r||}
\hline Capital Cost in , Million & 7.2 & 15.1 & 36 & 51 & 68 \\
\hline Specific Investment (,/kWe) & 5,620 & 4,500 & 2,890 & 2,690 & 2,350 \\
\hline BESP (p/kWh) ${ }^{* *}$ & $\mathbf{1 7 . 1}$ & $\mathbf{1 4 . 0}$ & $\mathbf{9 . 2}$ & $\mathbf{8 . 9}$ & $\mathbf{8 . 0}$ \\
\hline Wood Price (,/daf tonne) & 25.20 & 25.20 & 25.20 & 25.20 & 25.20 \\
\hline
\end{tabular}

** $\quad$ BESP $=$ Break-even Electricity Selling Price for 7.5\% DCF and stated fuel price.

\section{Simple Cycle Gas Turbines in the STIG and ISTIG Modes}

One of the turbines (LM5000) was also considered in the STIG and ISTIG configurations integrated into the simple cycle systems. Probably one of the most important advances in power production in recent times was the introduction in the early 1980s of the Steam-Injected Gas Turbine (STIG). This is a modification of the simple gas turbine, using the exhaust gases in a Heat Recovery Steam Generator (HRSG) to produce steam at various pressures, which is then injected into the combustor (and at other stage(s) in the expander), to be heated to the Turbine Inlet Temperature (TIT) and then expanded through the turbine stages. Compared with the simple cycle gas turbine, the only extra work involved comes from pumping the feedwater to the required boiler pressures, which is much smaller than the work required to compress the air flowing through the turbine. So, when steam is injected into the combustor, the compressor is required to do no additional work, while the flow (mass and energy) through the expander is increased (Larson, E.D. and Williams, R.H., 1985). The specific heat of steam is double that of air, which also enhances the flow of energy. This results in a considerable increase in power output and efficiency. By adding an intercooler between the early low pressure stages of the gas turbine's compressor further gains in performance can be achieved. This is called the Intercooled Steam-Injection Gas Turbine (ISTIG).

Results for these systems are summarised in the following table. The STIG and ISTIG systems were found to have higher efficiencies and lower BESP values than the system usingthe same turbine in the standard mode, as is shown in the following figures. 

Table 8. LM5000 in Standard SGT, STIG and ISTIG Configurations

\begin{tabular}{|l|r|r|r||}
\hline LM5000 SGT Configuration & Standard & STIG & ISTIG \\
\hline \hline Fuel Flow (daf Tonnes/day) & 660 & 970 & 1,950 \\
\hline Nominal Power Output (MWe) & 29.0 & 71.2 & 146 \\
\hline Overall Efficiency (LHV)(\%) & 21.9 & 36.4 & 37.2 \\
\hline CO $_{2}$ Emissions (g/kWh) & 1,740 & 1,050 & 1,020 \\
\hline Capital Cost in, Million & 68 & 124 & 214 \\
\hline Specific Investment (,/kWe) & 2,350 & 1,740 & 1,470 \\
\hline BESP (p/kWh) $* *$ & $\mathbf{8 . 0}$ & $\mathbf{5 . 6}$ & $\mathbf{5 . 0}$ \\
\hline Wood Price (,/daf tonne) & 25.20 & 25.10 & 27.17 \\
\hline
\end{tabular}

** $\quad$ BESP $=$ Break-even Electricity Selling Price for 7.5\% DCF and stated fuel price. 
BESP V. PLANT SIZE

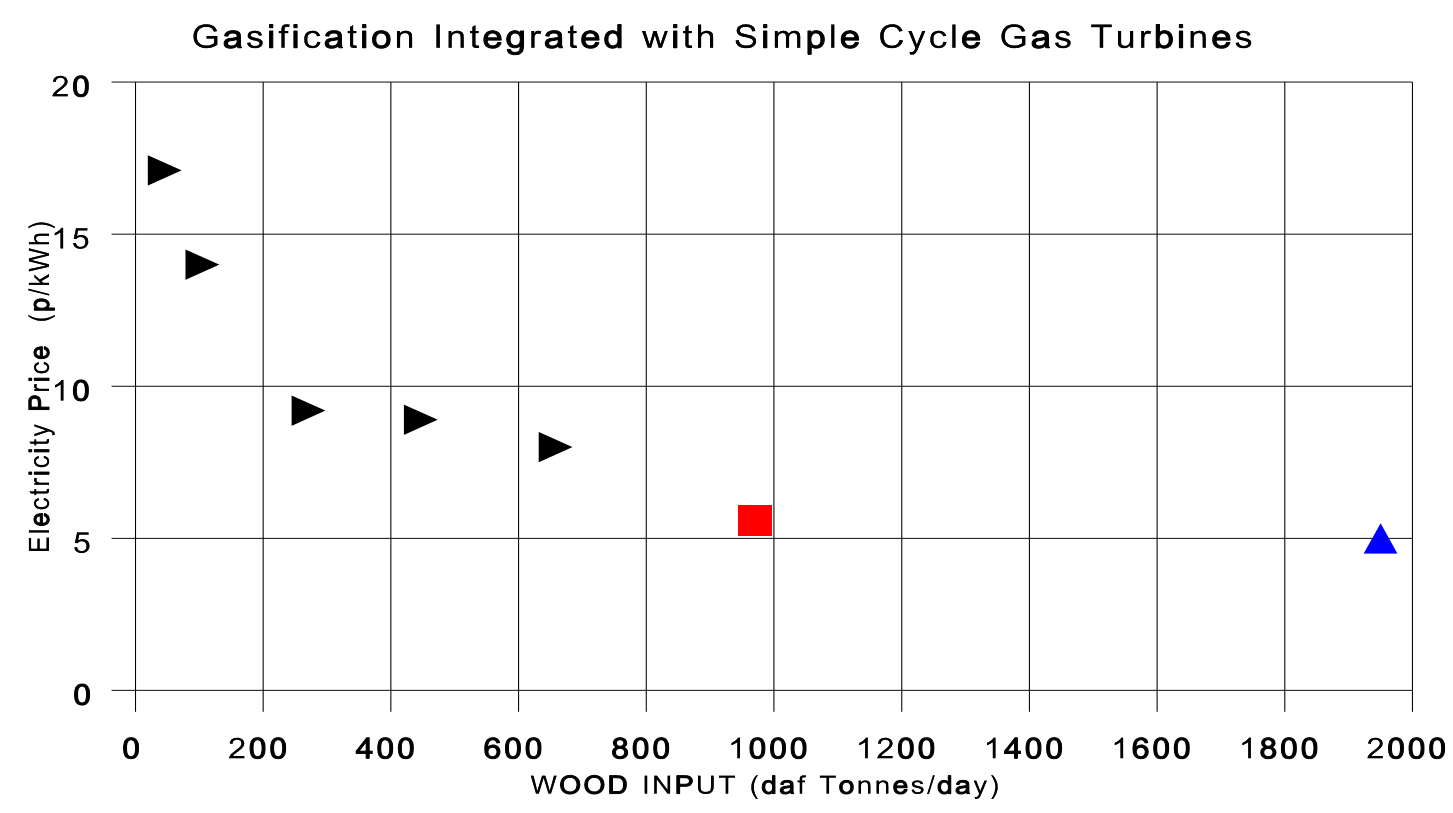

\begin{tabular}{|lllll|}
\hline & STIG & ISTIG & Standard \\
\hline
\end{tabular}

\section{EFFICIENCY v. PLANT SIZE}

Gasification Integrated with Simple Cycle Gas Turbines

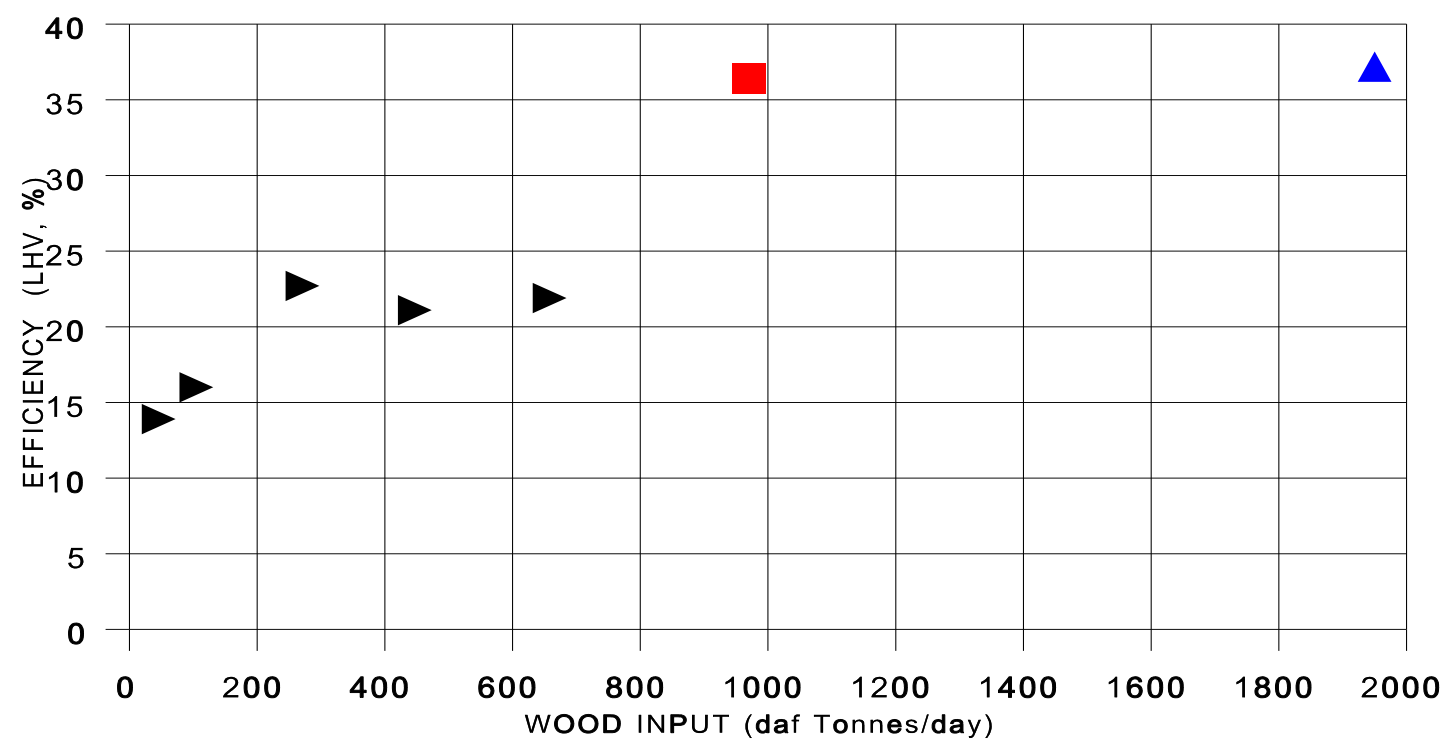

\begin{tabular}{|lllll|}
\hline STIG & $\Delta$ & ISTIG & Standard \\
\hline
\end{tabular}




\section{Summary for SGT Systems}

! The overall electricity generating efficiency was found to increase with plant size. For the LM5000 turbine, LHV electrical $\eta$ rises from $21.9 \%$ (Standard configuration) to $36.4 \%$ (STIG) and $37.2 \%$ (ISTIG).

! For these SGT systems there are no problems with wood availability or transportation costs. This also applies to the STIG system investigated, but the ISTIG system is almost too big (-2,000 dry tonnes/ day).

! Break-Even Electricity Selling Price (BESP) falls as the system efficiency and system size rises. SGT systems are not competitive for electricity generation (so no optimal size is suggested), but may be viable for CHP. STIG and ISTIG systems have similar BESPs to IGCC systems of the same size, at present. 


\section{Gasification Integrated with SI Gas Engines}

The simulations are based on the Spark-Ignited Generator sets produced by Caterpillar. Initially, the engines are simulated with natural gas as the fuel, since the manufacturer's specifications are given for this fuel. The electrical output, heat rejections, stack temperature, fuel consumption and air flow were reproduced in the simulation. Secondly, the simulation was repeated for each engine using wood producer gas as the fuel. The total volume flow of the wood gas/air mixture was kept the same as the natural gas/air mixture in the first simulation. The electrical output falls to about $70 \%$ of that for natural gas as fuel. The final simulation for each engine involved adding a suitably scaled gasifier (to produce the required wood gas flow) to the engine set-up of the second simulation.

Six engines were simulated in their turbo-charged after-cooled (TA) versions and twointhe naturally-aspirated (NA) versions.

The results for wood gasification integrated with spark ignition gas engines, featuring atmospheric pressure gasifiers and water scrubbers for cold gas cleaning, are summarised inthe following table and figures. 
Table 9. Gasifier/SI Gas Engines Systems - AGS Configuration

\begin{tabular}{|c|c|c|c|c|c|c|c|c|}
\hline $\begin{array}{l}\text { Fuel Flow (daf } \\
\text { Tonnes/day) }\end{array}$ & 2.8 & 3.8 & 6.6 & 9.0 & 17.1 & 22.3 & 33.1 & 44.5 \\
\hline $\begin{array}{l}\text { Nominal Power } \\
\text { Output (MWe) }\end{array}$ & 0.15 & 0.17 & 0.30 & 0.54 & 0.83 & 1.10 & 1.66 & 2.27 \\
\hline $\begin{array}{l}\text { Overall } \\
\text { Efficiency } \\
(\mathrm{LHV})(\%)\end{array}$ & 26.6 & 22.6 & 22.8 & 29.7 & 24.2 & 24.6 & 25.0 & 25.4 \\
\hline $\begin{array}{l}\mathrm{CO}_{2} \text { Emissions } \\
(\mathrm{g} / \mathrm{kWh})\end{array}$ & 1,430 & 1,685 & 1,670 & 1,280 & 1,580 & 1,550 & 1,530 & 1,500 \\
\hline $\begin{array}{l}\text { Capital Cost } \\
\text { (, Million) }\end{array}$ & 0.3 & 0.3 & 0.5 & 0.7 & 1.3 & 1.8 & 2.6 & 3.5 \\
\hline Engine Model & $3408 \mathrm{TA}$ & 3408NA & $3516 \mathrm{NA}$ & $3516 \mathrm{TA}$ & $3606 \mathrm{TA}$ & $3608 \mathrm{TA}$ & $3612 \mathrm{TA}$ & $3616 \mathrm{TA}$ \\
\hline $\begin{array}{l}\text { Specific } \\
\text { Investment } \\
(, / \mathrm{kWe})\end{array}$ & 1,870 & 1,860 & 1,610 & 1,210 & 1,560 & 1,630 & 1,570 & 1,520 \\
\hline $\begin{array}{l}\text { BESP } \\
(\mathrm{p} / \mathrm{kWh})^{* *}\end{array}$ & 6.0 & 6.3 & 5.7 & 4.3 & 5.5 & 5.6 & 5.4 & 5.3 \\
\hline $\begin{array}{l}\text { Wood Price } \\
\text { (,/daf tonne) }\end{array}$ & 19.93 & 19.95 & 19.99 & 20.02 & 20.11 & 20.15 & 20.23 & 20.30 \\
\hline
\end{tabular}

** $\quad$ BESP $=$ Break-even Electricity Selling Price for 7.5\% DCF and stated fuel price.

\section{Summary for Gasifier/ Gas Engine Systems}

! $\quad$ Efficiencies are moderate, but plant sizes are small.

! Break-Even Electricity Selling Price (BESP) was found to be about the same for all but the smallest plant sizes, so almost the whole size range can be considered.

! BESP values are comparable with those of most IGCC systems, which are much 


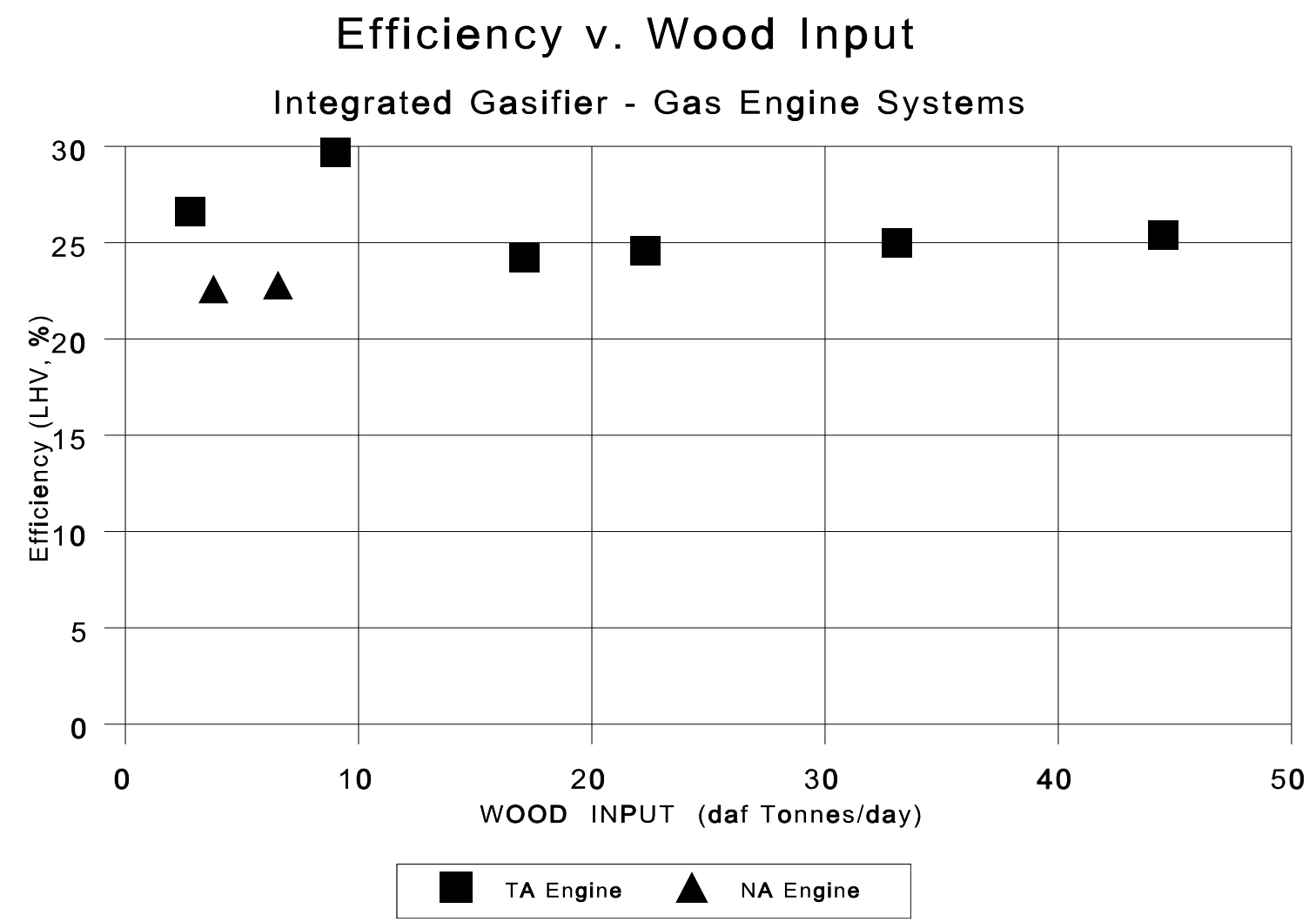

larger.

BESP v. Wood Input

Integrated Gasifier - Gas Engine Systems (DCF at $7.5 \%$ )

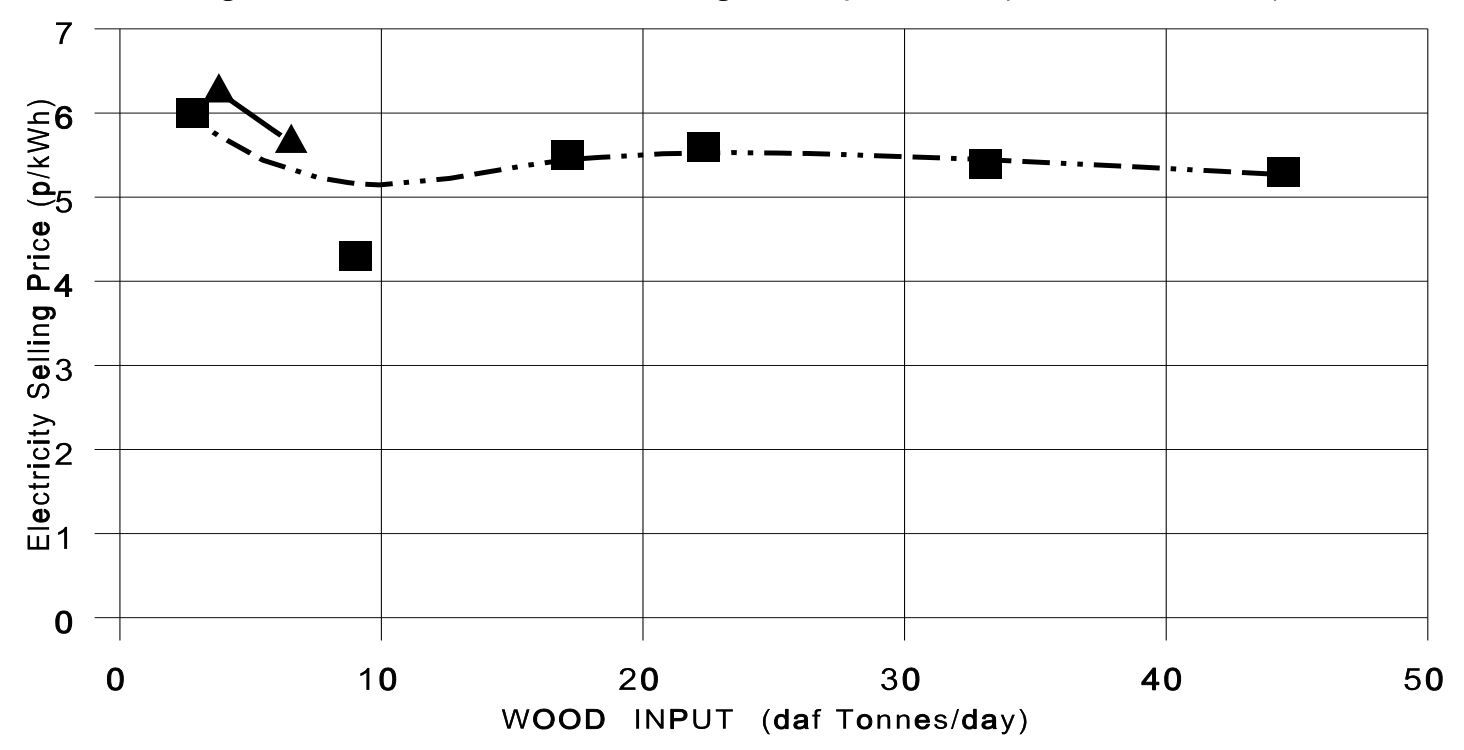

TA Engine $\triangle$ NA Engine 


\section{Gasification Integrated with Fuel Cells}

\section{LPO Gasifier Integrated with PAFC Systems}

The PAFC is a low temperature fuelcell which operates at 200EC with an electrical efficiency of $40 \%$ and can deliver waste heat between 80EC and 120EC (CEC report, 1991). The electrolyte is concentrated orthophosphoric acid (contained in a supporting matrix of PTFEbonded silicon carbide) and the electrodes are carbon black particles supported on carbonimpregnated, conducting paper (Scott D.H., 1993). The platinum catalyst is carried on the particles of carbon black. At the anode (negative electrode) the hydrogen-rich gas passes over the backing paper and diffuses through it. As it passes through the narrow pores of the anode, electrons can be stripped from the hydrogen atom in the presence of the catalyst. The electrons are free to be removed into an external circuit, providing electricity. The hydrogen ions produced pass on into the electrolyte. Oxygen (from air or an oxidant) is introduced at the cathode. It can react, in the presence of the catalyst with any free electrons present (usually provided when current is flowing in the external load circuit) and the hydrogen ions in the electrolyte at the cathode-electrolyte interface to produce $\mathrm{H}_{2} \mathrm{O}$ in the form of steam.

This can be summarised as:

Anode: $\mathrm{H}_{2} 62 \mathrm{H}^{+}+2 \mathrm{e}^{-}$(to external circuit)

Cathode: $2 \mathrm{O}_{2}+2 \mathrm{H}^{+}+2 \mathrm{e}^{-}$(from external circuit) $6 \mathrm{H}_{2} \mathrm{O}$

The PAFC has no problem in handling carbon dioxide, but can only tolerate carbon monoxide and hydrogen sulphide in very small concentrations (a few ppm for $\mathrm{H}_{2} \mathrm{~S}$, and less than $1-2 \%$ for $\mathrm{CO})$.

The results for wood gasification integrated with phosphoric acid fuel cells, featuring atmospheric pressure oxygen-blown (LPO) gasifiers and wet scrubbers for cold gas cleaning, are summarised in the following table and figures. 
Table 10. Gasifier/ PAFC Engines Systems

\begin{tabular}{|l|r|r|r|r|r|r|r|r|r||}
\hline $\begin{array}{l}\text { Fuel Flow (daf } \\
\text { Tonnes/day) }\end{array}$ & 0.6 & 1.0 & 1.3 & 1.8 & 2.4 & 2.6 & 6.7 & 11.2 & 15.1 \\
\hline $\begin{array}{l}\text { Nominal Power Output } \\
\text { (MWe) }\end{array}$ & 15 & 30 & 40 & 55 & 75 & 80 & 220 & 370 & 500 \\
\hline $\begin{array}{l}\text { Overall Efficiency } \\
\text { (LHV)(\%) }\end{array}$ & 13.7 & 14.4 & 14.7 & 15.0 & 15.4 & 15.4 & 16.1 & 16.4 & 16.6 \\
\hline $\begin{array}{l}\text { CO }{ }_{2} \text { Emissions (g/kWh) } \\
\text { Capital Cost (, Million) }\end{array}$ & 0.11 & 0.19 & 0.23 & 0.29 & 0.36 & 0.38 & 0.86 & 1.30 & 1.68 \\
\hline $\begin{array}{l}\text { Specific Investment } \\
(, / \mathrm{kWe})\end{array}$ & 7,200 & 6,200 & 5,700 & 5,200 & 4,800 & 4,700 & 3,900 & 3,500 & 3,300 \\
\hline BESP (p/kWh) & 19.90 & 19.90 & 19.90 & 19.90 & 19.90 & 19.90 & 19.90 & 19.90 & 25.20 \\
\hline Wood Price (,/daf tonne) & $\mathbf{1 9 . 5}$ & $\mathbf{1 7 . 0}$ & $\mathbf{1 5 . 8}$ & $\mathbf{1 4 . 7}$ & $\mathbf{1 3 . 8}$ & $\mathbf{1 3 . 5}$ & $\mathbf{1 1 . 4}$ & $\mathbf{1 0 . 6}$ & $\mathbf{1 0 . 8}$ \\
\hline \hline
\end{tabular}

\section{Efficiency v. Wood Input}

Integrated Gasifier - PAFC Systems

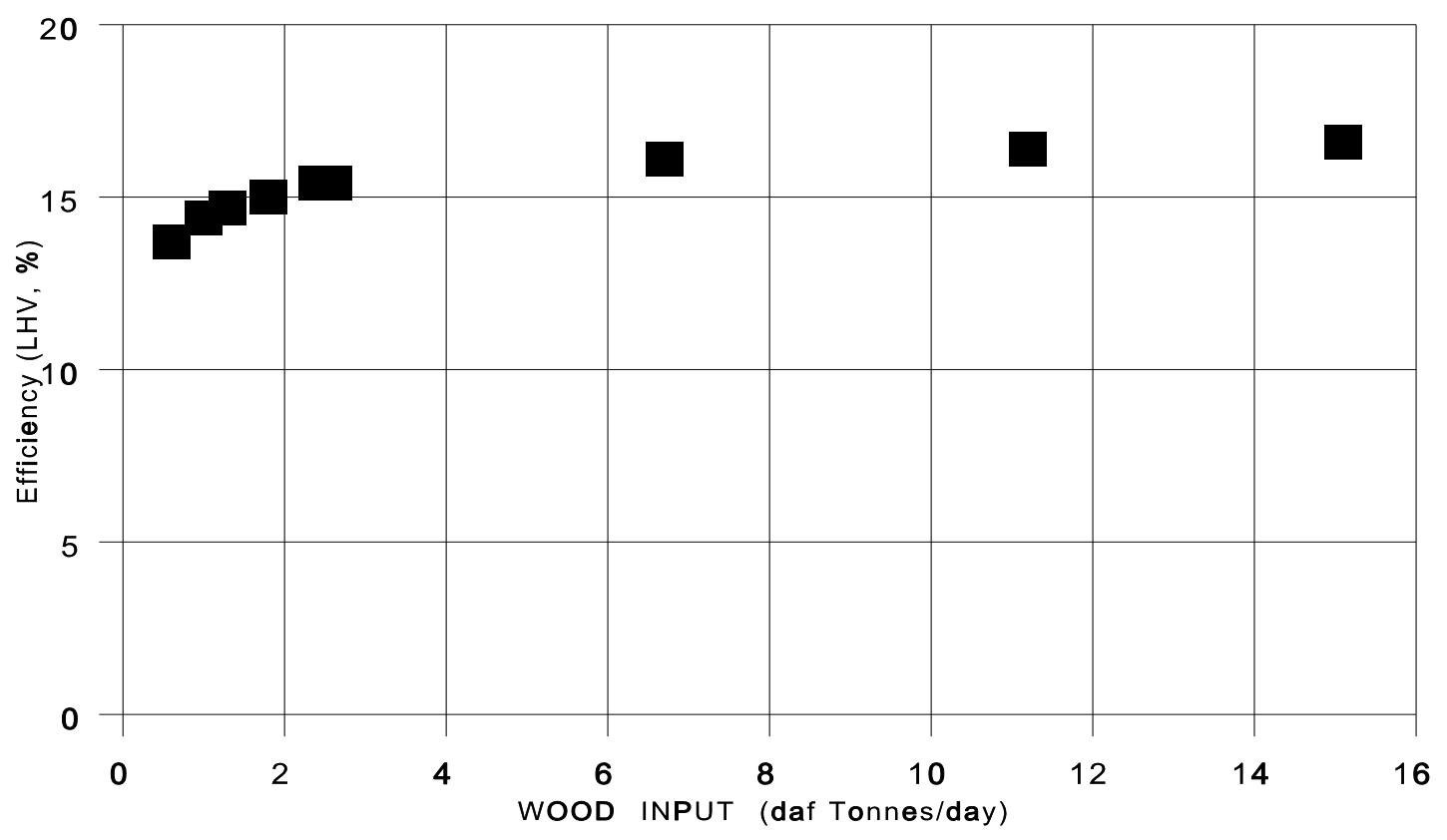




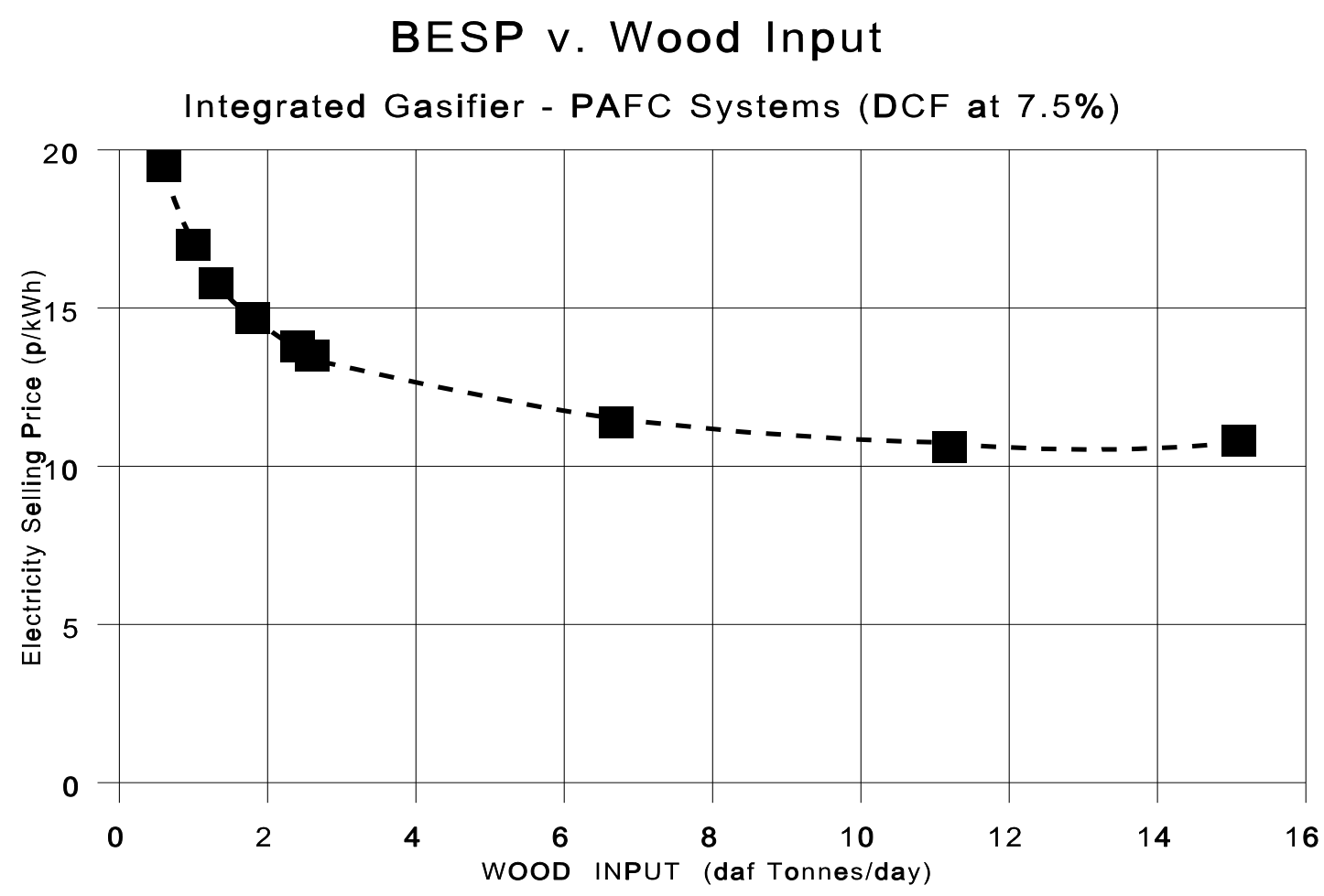

** $\quad$ BESP $=$ Break-even Electricity Selling Price for 7.5\% DCF and stated fuel price.

\section{LPO Gasifier Integrated with MCFC System}

The MCFC is a high temperature fuel cell operation at 650EC. At this temperature the electrolyte, composed of a mixture of lithium carbonate with sodium and/or potassium carbonate, is in the molten state. It is retained in a lithium aluminate matrix. The anode is porous nickel with a few percent of chromium oxide and the cathode is made of porous nickel oxide(containing some lithium). The main components of the fuel are carbon monoxide and hydrogen, which can be found in natural gas or produced from the gasification of coal or biomass, or from naphtha, LPG or methanol. In a high temperature fuel cell the carbon monoxide can be converted into hydrogen in a process known as internal reforming through the action of a catalyst contained in the anode. Internal reforming is expected to increase the efficiency of this fuel cell, as well as reducing costs by eliminating the expense of providing an external reformer. The MCFC is unusual in that it actually requires the presence of carbon dioxide for the fuel cell to continue operating.

The main reactions can be summarised as follows;

Anode: $\mathrm{H}_{2}+\mathrm{CO}_{3}^{--} 6 \mathrm{H}_{2} \mathrm{O}+\mathrm{CO}_{2}+2 \mathrm{e}^{-}$ 
Cathode: $2 \mathrm{O}_{2}+\mathrm{CO}_{2}+2 \mathrm{e}^{-} 6 \mathrm{CO}_{3}^{--}$

Oxygen reacts with carbon dioxide at the cathode and free electrons to produce carbonate ions. The carbonate ions carry the ionic current through the electrolyte from cathode to anode. Hydrogen is oxidised to water (vapour) at the anode in a reaction with the carbonate ions, releasing electrons. The carbon dioxide produced at the anode must be recycled to the cathode to prevent the cell from becoming polarised and cease operating.

MCFCs are not yet at the commercial stage, it is about five years behind the PAFC in development, but efficiencies of 50-60\% are expected to be readily achievable (Mugerwa M.N. and Blomen, L.J., 1993).

The results for wood gasification integrated with molten carbonate fuel cells, featuring atmospheric pressure oxygen-blown (LPO) gasifiers and wet scrubbers for cold gas cleaning, are summarised in the following table and figures.

Table 11. Gasifier/MCFC Engines Systems

\begin{tabular}{|c|c|c|c|c|c|c|c|c|}
\hline $\begin{array}{l}\text { Fuel Flow (daf } \\
\text { Tonnes/day) }\end{array}$ & 0.3 & 0.5 & 0.7 & 1.0 & 1.5 & 3.2 & 6.7 & 8.9 \\
\hline $\begin{array}{l}\text { Nominal Power Output } \\
\text { (MWe) }\end{array}$ & 15 & 30 & 40 & 55 & 80 & 175 & 380 & 505 \\
\hline $\begin{array}{l}\text { Overall Efficiency } \\
(\mathrm{LHV})(\%)\end{array}$ & 24.8 & 25.6 & 25.9 & 26.4 & 26.8 & 27.5 & 28.1 & 28.3 \\
\hline $\mathrm{CO}_{2}$ Emissions $(\mathrm{g} / \mathrm{kWh})$ & 1,530 & 1,490 & 1,470 & 1,440 & 1,420 & 1,380 & 1,360 & 1,350 \\
\hline Capital Cost (, Million) & 0.07 & 0.11 & 0.14 & 0.18 & 0.24 & 0.44 & 0.84 & 1.03 \\
\hline $\begin{array}{l}\text { Specific Investment } \\
(, / \mathrm{kWe})\end{array}$ & 4,700 & 3,800 & 3,500 & 3,200 & 3,000 & 2,500 & 2,200 & 2,050 \\
\hline $\operatorname{BESP}(\mathrm{p} / \mathrm{kWh})^{* *}$ & 12.4 & 10.3 & 9.6 & 9.0 & 8.3 & 7.2 & 6.4 & 6.5 \\
\hline Wood Price (,/daf tonne) & 19.90 & 19.90 & 19.90 & 19.90 & 19.90 & 19.90 & 19.90 & 25.20 \\
\hline
\end{tabular}




\section{Efficiency v. Wood Input}

Integrated Gasifier - MCFC Systems

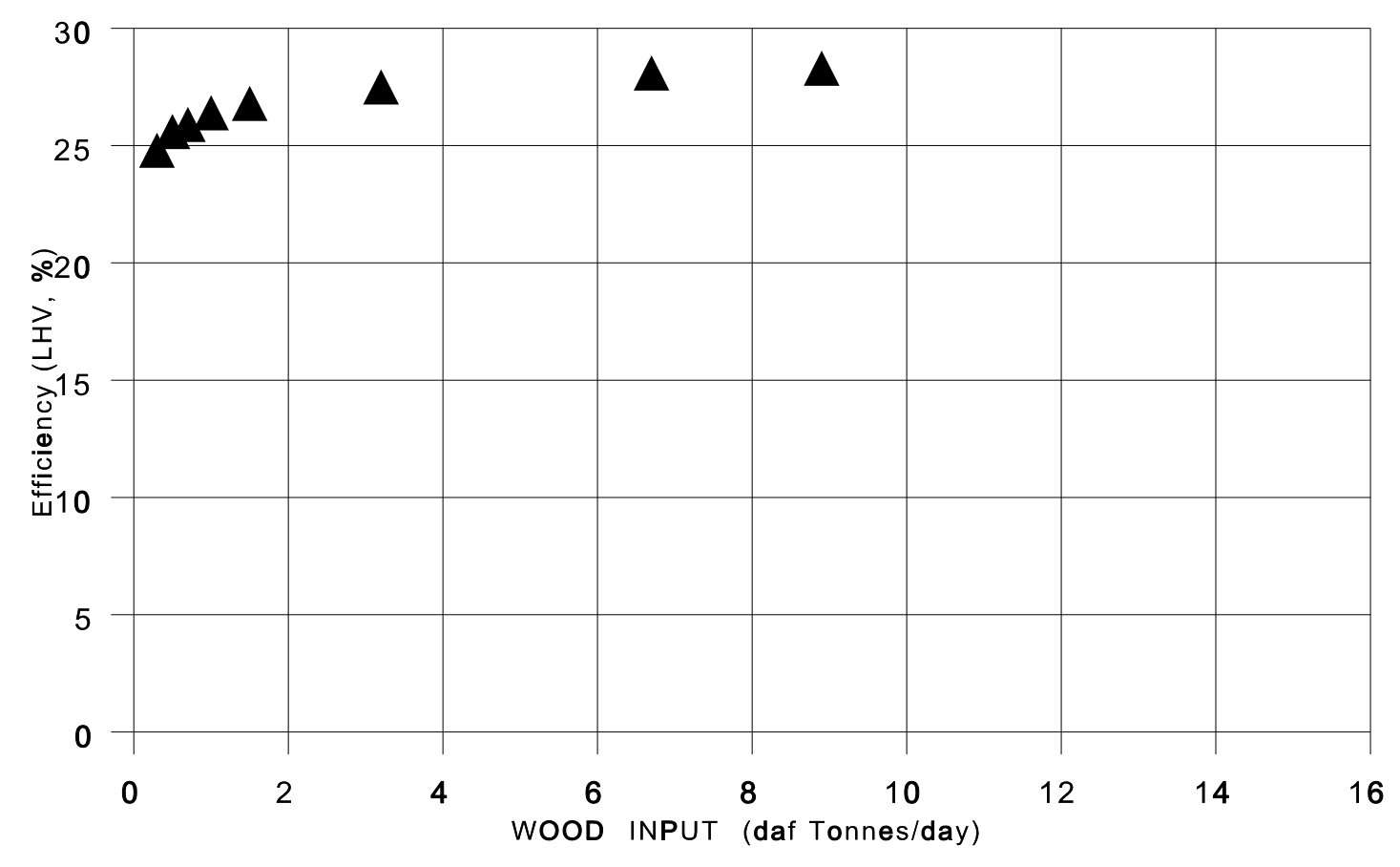

** $\quad$ BESP $=$ Break-even Electricity Selling Price for 7.5\% DCF and stated fuel price. 


\section{Efficiency v. Wood Input}

Small Scale Systems

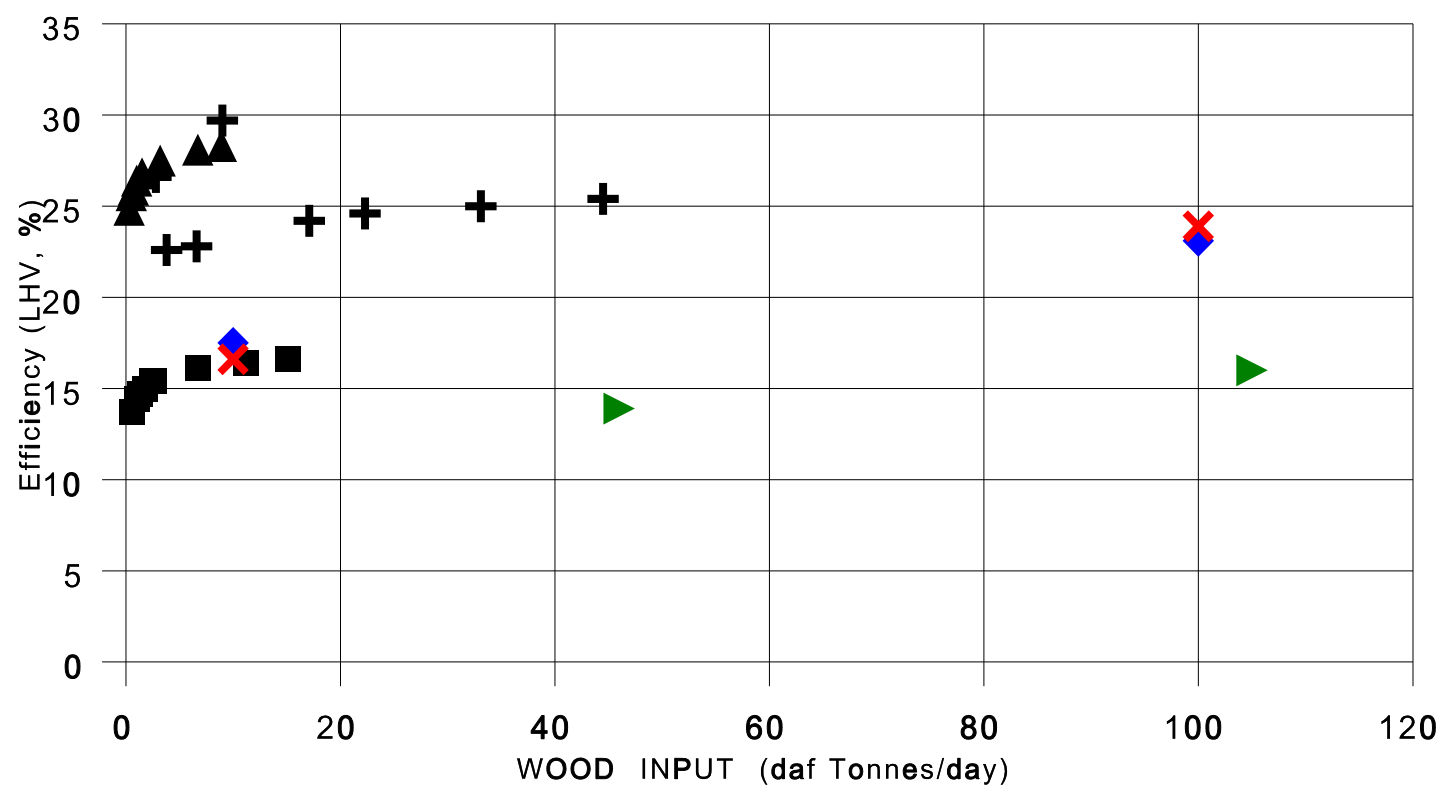
PAFC
Comb (Wet)
MCFC
Comb (Dried)
Hengine

BESP v. Wood Input

Integrated Gasifier - MCFC Systems (DCF at 7.5\%)

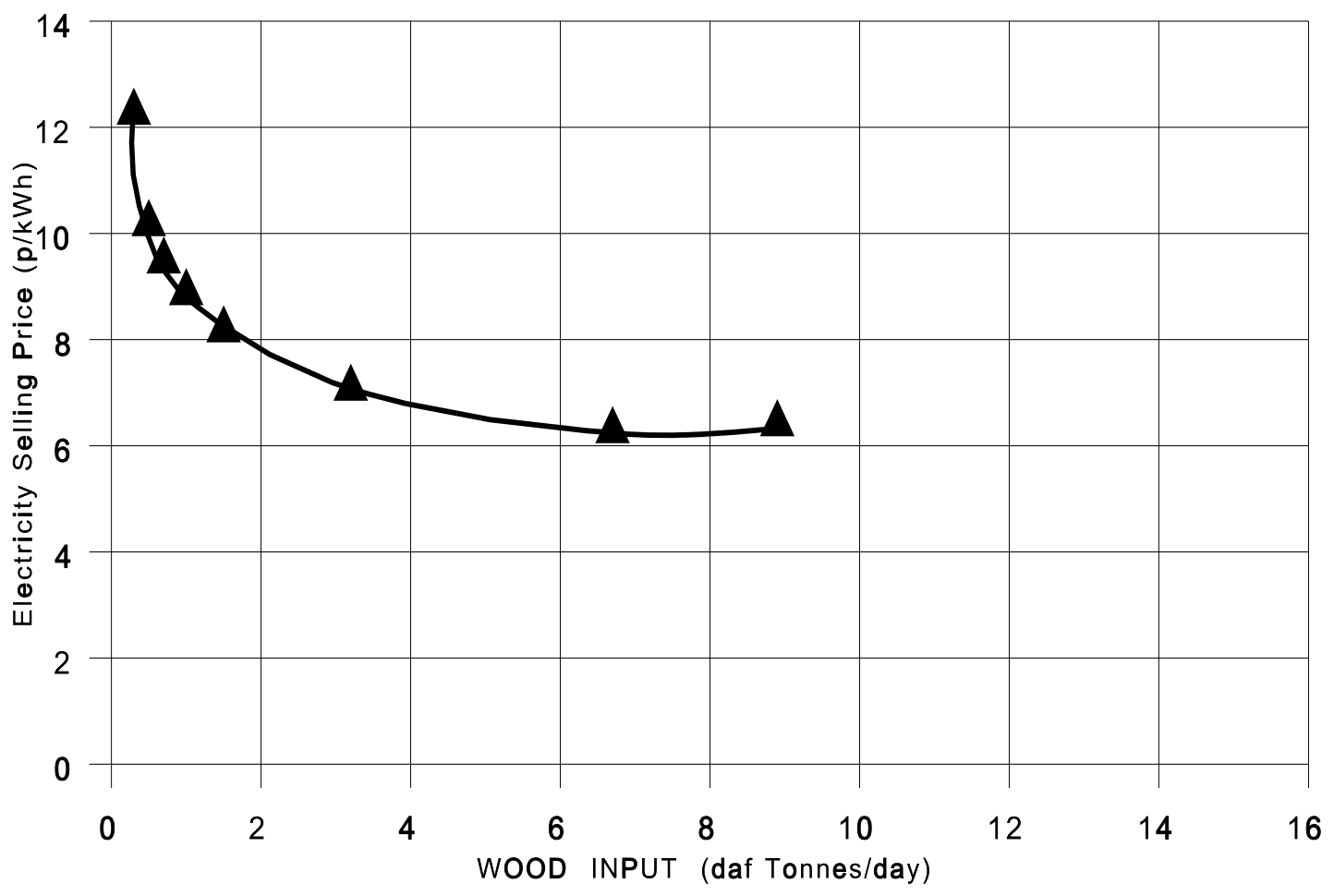




\section{Summary of LPO Gasifier/ Fuel Cell Systems}

! The MCFC system has the highest efficiency of the small systems. The PAFC has an efficiency similar to that of wood combustion plants of similar size (i.e. wood input).

! BESP values are better than for similarly sized wood combustion plants, but are expected to be higher than those of the gas engine systems.

! All of these systems use downdraft gasifiers integrated with fuel cells. The fuel cells are modular, so their capital cost increases linearly with the number of modules used. Gasifier costs are exponential, but they are capped by the limit of the technology i.e. downdraft gasifiers do not yet work at large scale (above about $2 \mathrm{MW}$ thermal). If system output of electricity is to be increased, more than one gasifier must be used. BESP fall sharply with increased size for the smallest systems, then falls more gradually. In the graph it is shown to rise for the largest size, where the feedstock cost has increased due to transportation costs. (If increased transportation costs were not considered, the BESP value for the largest PAFC system would be $10.2 \mathrm{p} / \mathrm{kWh}$ instead of $10.8 \mathrm{p} / \mathrm{kWh}$, and for the MCFC system it would be $6.1 \mathrm{p} / \mathrm{kWh}$ instead of $6.5 \mathrm{p} / \mathrm{kWh}$ ). The optimum plant size for a single LPO downdraft gasifier integrated with PAFC or MCFC fuel cells would be in the range 300-500 kWe.

\section{Conclusions on Wood-fired Technologies}

\section{Comparison of Small Scale Systems}

In this work a small scale system is considered to be one which uses less than 120 daftonnes/ day of wood feedstock.

For the very smallest systems, using less than 20 daf tonnes/ day, the gasification plants with PAFCs and the combustion plants have been found to be the least efficient, whereas the gasification plants with MCFCs or engines were the most efficient. The plants which are most efficient have also the lowest BESP values, and those found to be least efficient have the highest BESP values.

For the largest systems in this size range, using around 100 daf tonnes/ day, 
.combustion plants have higher efficiencies and lower BESP values than the gasification systems

\section{EFFICIENCY V. PLANT SIZE}

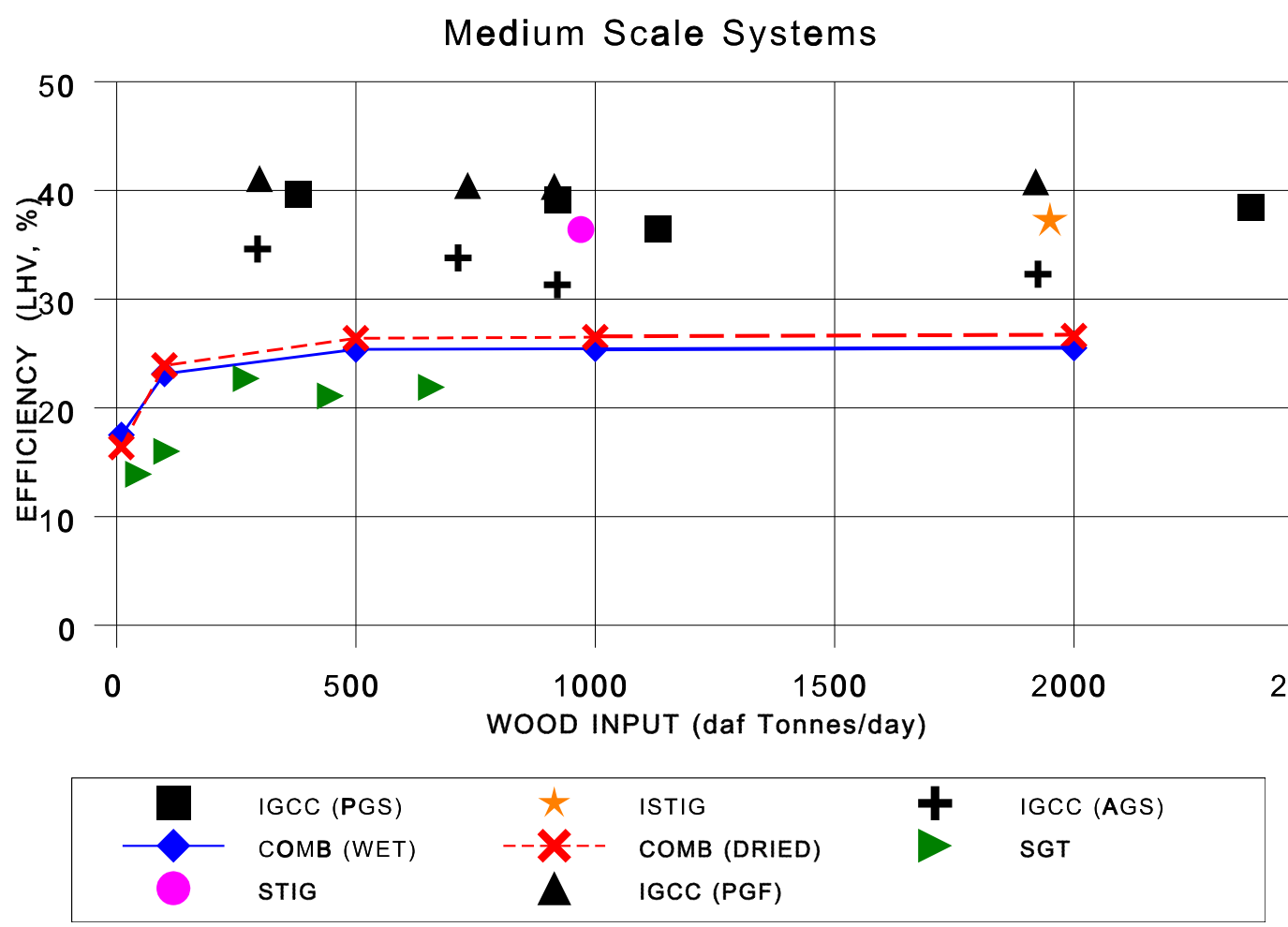

using gas turbines in a simple cycle (SGT systems).

Since the MCFC technology is not yet developed to a commercial level, gasificationsystems using gas engines would appear to be the most appropriate for small scale systems using biomass feedstock

\section{Comparison of Medium Scale Systems}

In this work medium scale systems are those which use between around 100 and 2,000 daf tonnes/ day of wood feedstock. Efficiencies and BESP values were found to be almost constant for each technology throughout this range of plant sizes, except for the 
smallest (below about 200 daf tonnes/ day. The SGT systems were found to be the least efficient in this size range, and to have the highest BESP values. However, the SGT systems which employs the gas turbine in the STIG mode is among the most efficient of medium scale systems, and to have a BESP value comparable with the lowest in this range. The combustion systems were found to be more efficient than the SGTs, but less efficient than all the IGCC variations. The IGCC systems were found to be the most efficient, the pressurised versions being more efficient than those operating at atmospheric pressures, but BESP values were similar for all IGCC systems in this range. Surprisingly, perhaps, the less efficient combustion systems were found to have slightly lower BESP values than the IGCC systems. The difference

\section{BESP v. Wood Input}

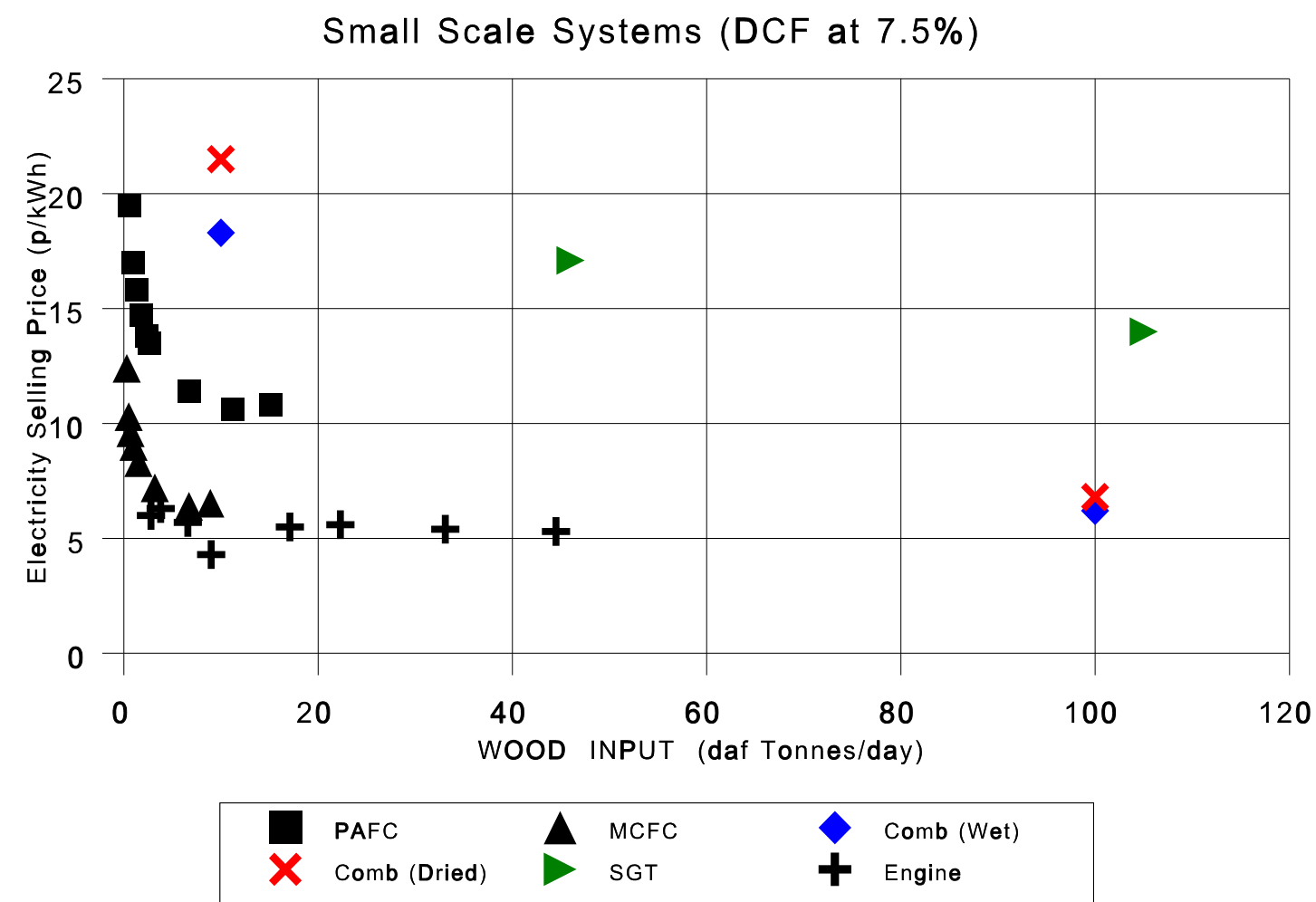

between BESP values for combustion systems and IGCC systems lies within the "30\% margin of error for the economic analysis as performed by ECLIPSE, so such small variations should not be given undue significance. 


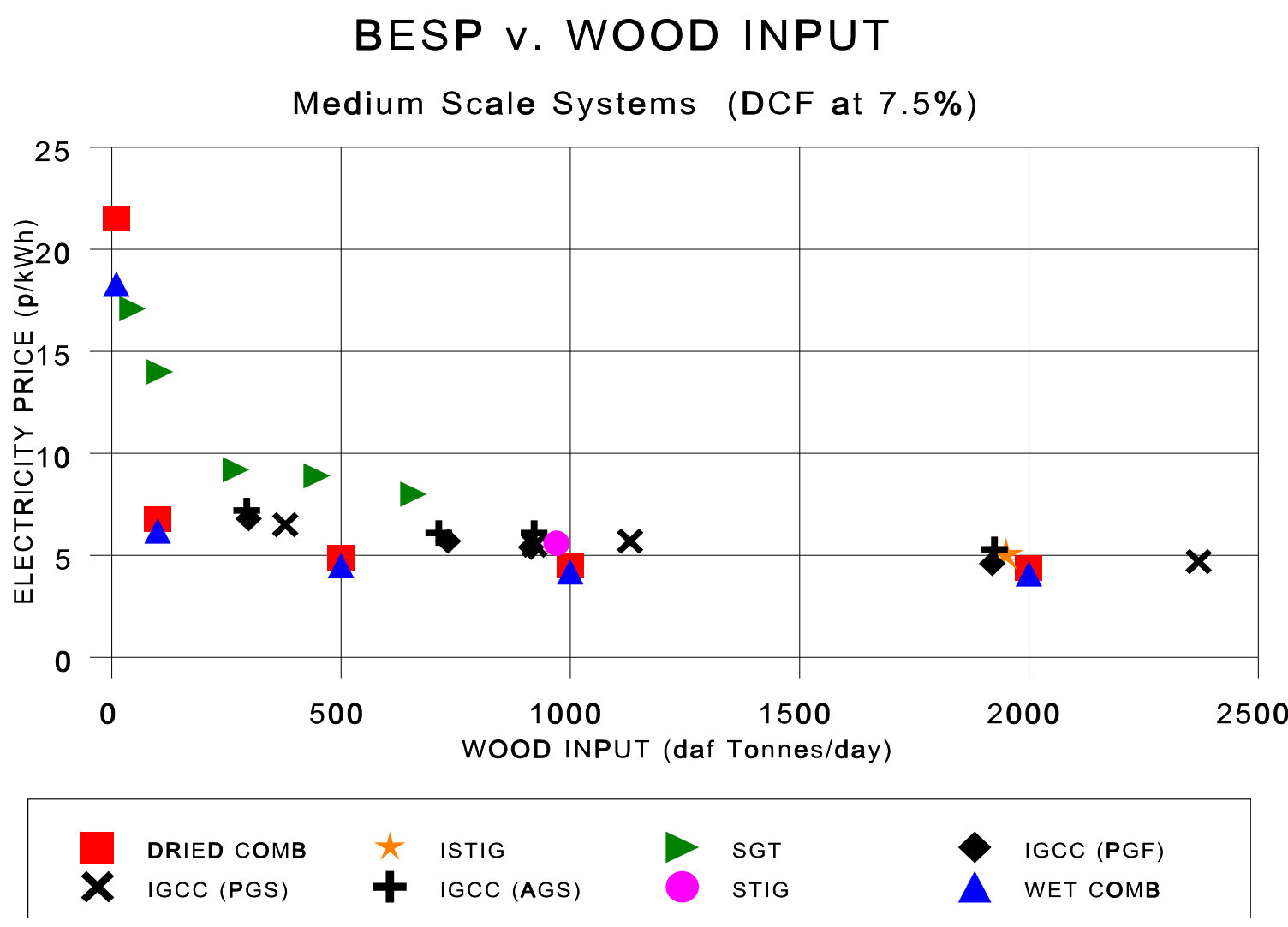

\section{References}

Bridgwater, A.V. and Double, J.M., Technical and economic processes for liquid fuel production in Europe. Contract EN3V-0012-UK(RH) for the Non-nuclear programme of the Commission of the European Communities, 1991.

Commission of the European Communities, New Ways to Save Energy: Fuel Cells and Batteries, a DG XII report of the EC Non-Nuclear Energy R\&D Programme Energy Conservation, 1991.

Dawson M., DANI, private communication 1992 or ETSU report Wood Fuel Supply Strategies, Vol.1, Report Nr. ETSU B 1176-P1, 1993. 
Hall, D.O., Rosillo-Calle, F., Williams, R.H. and Woods, J., Biomass for Energy: Supply Prospects. Chapter 14 of Renewable Energy: Sources for Fuel and Electricity, Earthscan, London, UK, 1993, 593-651.

Larson E.D. and Williams R.H., "Technical and Economic Analysis of Steam-Injected GasTurbine Cogeneration", Chapter 21 of Energy Sources: Conservation and Renewables, APS, Washington, 1985, 402-425.

McIlveen-Wright D.R., "Electricity Generation from Wood", DPhil. Thesis, University of Ulster, Coleraine, 1995.

McIlveen-Wright D., Sloan P.E., Williams B.C. and McMullan J.T., "A Comparison of Electricity Generation from Wood Combustion and IGCC Plants using Wood Feedstock", Proceedings of the Lisbon Conference on Combustion Technology for a Clean Environment, Volume II, July 1995, 7-12.

McIlveen-Wright D., Sloan P.E., Williams B.C. and McMullan J.T., "Wood-Fired Combustion Plants", Proceedings of the 2nd International Conference on Combustion and Emission Control, Institute of Energy, London, Dec. 1995, 179188.

Mcllveen-Wright D.R., AWood-Fired Fuel Cells@, MSc. Environmental Management thesis, University of Ulster, Coleraine, 1996, 108pp.

McIlveen-Wright, D.R, Williams, B.C. and McMullan, J.T., Electricity Generation from Wood-Fired Power Plants: The Principal Technologies Reviewed, Developments in Thermochemical Biomass Conversion, Volume 2, eds., Bridgwater A.V. and Boocock D.G.B., Blackie Academic and Professional, London, UK, 1997, 15251538. 
McMullan, J.T., Williams, B.C., Campbell, P., McIlveen-Wright, D. and Bemtgen J.M., Techno-economic assessment studies of fossil fuel and fuel wood power generation technologies. CEC report, contract nr. JOUF-0017, 1995.

Mugerwa M.N. and Blomen L.J., "System Design and Optimisation", in Fuel Cell Systems, (eds., Blomen L.J. and Mugerwa M.N.), PlenumPress, New York, 1993, 211.

Scott D.H., Advanced Power Generation from Fuel Cells - Implications for Coal, IEA Coal Research, London, 1993, 74pp.

Solantausta, Y., Bridgwater, A.V. and Beckman, D., An assessment of biomass based power systems. Report for the International Energy Agency Bioenergy Agreement, (VTT), 1995.

Williams, B.C. and McMullan, J.T., Techno-economic analysis of fuel conversion and pover generation systems - the development of a portable chemical process simulator with capital cost and economic performance analysis capabilities Int. J. Energy Research, 1996,20, 125-142,

\section{OR}

Williams B.C. The development of the ECLIPSE simulator and its application to the thoeconomic assessment of clean fossil fuel power generation systems. DPhil thesis, University of Ulster, Coleraine, N. Ireland, UK, 1994. 

